Federal Reserve Bank of Minneapolis

Research Department Staff Report 204/JV

\title{
The Poverty of Nations: A Quantitative Investigation
}

\author{
V. V. Chari* \\ University of Minnesota \\ and Federal Reserve Bank of Minneapolis
}

Patrick J. Kehoe*

University of Pennsylvania

Federal Reserve Bank of Minneapolis

Ellen R. McGrattan*

Federal Reserve Bank of Minneapolis

\begin{abstract}
We ask what fraction of the variation in incomes across countries can be accounted for by investment distortions. In our neoclassical growth model the relative price of investment to consumption is a good measure of the distortions. Using data on relative prices we estimate a stochastic process for distortions and compare the resulting variance of incomes in the model to that in the data. We find that the variation of incomes in the model is roughly $4 / 5$ of the variability of incomes in the data. Our model does well in accounting for 6 key regularities on income and investment in the data.

*We thank Dan Chin for research assistance. The views expressed herein are those of the authors and not necessarily those of the Federal Reserve Bank of Minneapolis or the Federal Reserve System.
\end{abstract}




\section{Introduction}

The purpose of this paper is to ask what fraction of the variation in incomes across countries can be accounted for by distortions affecting capital accumulation. To answer this question we use a neoclassical growth model with distortions to investment. In our model economy the relative price of investment to consumption is a good measure of the distortions. We use data on relative prices to estimate a stochastic process for distortions which is common to all countries. We embed this stochastic process in our model and compare the variation of incomes in the model to that in the data. We find that the variation of incomes in the model is roughly $4 / 5$ of the variation of incomes in the data.

Our model does fairly well in accounting for key regularities in the data on the distribution of income and the patterns of investment across countries. Our data consists of a panel of 125 countries from 1960-1985 constructed by Summers and Heston (1991). We use output per worker relative to the world average output per worker as our measure of income. We focus on six regularities: (1) there is a large disparity in incomes; (2) countries in the middle of the world income distribution show more mobility than countries at the extremes; (3) growth rates in income are not persistent, while investment-output ratios are highly persistent; (4) there have been both development miracles and disasters; (5) given initial income, investment rates of countries that move up in the world income distribution are higher than those that do not; and (6) countries with high output per worker have high capital-output ratios.

Our model is a neoclassical growth model with a broad measure of capital in which investment decisions are affected by stochastic distortions. The recent literature in the neoclassical tradition (see, for example, Barro and Sala-i-Martin 1995, Mankiw, Romer, and Weil 1992, and Parente and Prescott 1994) emphasizes that a broad measure of capital is needed to account for at least some of the regularities in the data. One interpretation of this broad measure of capital is that it represents both physical capital and organization capital. An extensive literature has discussed the concept of organization capital (see, for example, Arrow 1962, Becker 1993, Prescott and Boyd 1987, Prescott 
and Visscher 1980, and Rosen 1972).

Regularities (5) and (6), namely the positive correlation of investment and growth and the positive correlation of capital-output ratios and relative incomes, suggest a model in which variations in investment-output ratios play a central role in generating variations in incomes. Distortions seemed like natural candidates to generate variations in investment rates. Many authors have emphasized disincentives to investment arising from corruption, inefficient bureaucracies, and resistance to technology adoption (see, for example, de Soto 1989). We think of the distortions in our model as a simple way of capturing these disincentives. Distortions of these kinds typically raise the prices of investment goods relative to those of consumption goods. Indeed in the data, investment goods prices are low in rich countries and high in poor countries. This observation drove us to construct a model in which distortions raise the relative price of investment goods. A substantial empirical literature has emphasized the role of distortions in determining the poverty of nations (see, for example, Barro 1991, DeLong and Summers 1991, Easterly 1993, and Jones 1994). In particular, Jones (1994) has argued that variations in investment goods prices play an important role in accounting for the variation in incomes.

Two additional features of the data drove us to make these distortions stochastic. The first is regularity (3), namely that growth rates of relative incomes show little persistence. Neoclassical growth models with no stochastic distortions are typically inconsistent with this feature of the data. The second is that in the data the relative price of investment goods fluctuates a good deal within each country.

Summers and Heston (1991) provide a panel data set on the relative prices of investment goods that we use to measure the distortions. We estimate a regime switching process (see Hamilton 1994) for the stochastic process governing distortions. We find that the data is well-characterized by a process with two regimes. In one regime the distortions are highly persistent over time and in the other they are more volatile. We embed the estimated regime switching process for distortions into a standard neoclassical growth model with a broad measure of capital. We use the model to 
generate a panel of 125 countries for 26 years with initial conditions on relative income chosen to match those in the data for 1960. We then compare this panel to the corresponding panel in the data for the period 1960 to 1985 . Our measure of the variability in income is the variance of the logarithm of incomes in 1985 . This variance is 0.88 in our model and 1.12 in the data. In this sense, our model accounts for $79 \%(=0.88 / 1.12)$ of the variability of incomes in the data. There are obviously many factors that lead to variability in incomes across countries. Our finding suggests that distortions which affect capital accumulation are potentially very important.

We compare the model and the data along a variety of dimensions. Our model does fairly well in accounting for a number of features of the data including the six regularities mentioned above. A key test of models of growth and development is their ability to produce economic miracles. Lucas has argued that: "If we understand the process of economic growth-or of anything else-we ought to be capable of demonstrating this knowledge by creating it in these pen and paper (and computer-equipped) laboratories of ours. If we know what an economic miracle is we ought to be able to make one." (See Lucas 1993, page 271.) Our model economy does indeed make miracles as well as disasters.

In our model we have focused on intertemporal distortions which affect incentives to invest. Some of the distortions discussed in the literature are static distortions that reduce the level of output for any given level of inputs. These distortions are equivalent to differences in the level of technology. A standard result is that along a balanced growth path of an economy with a CobbDouglas production, capital-output ratios do not depend on the level of technology. This result means that, along a balanced growth path, if the only difference between a rich country and a poor country is the level of static distortions, then their capital-output ratios and their investment rates should be the same. In the data, capital-output ratios differ systematically with the level of income. Given this fact and the implication of the theory, in models like ours, it seems like the only choices are to allow intertemporal distortions to play some role or to construct models in which countries are far from the balanced growth path. The richest countries are typically thought of as being 
approximately on a balanced growth path. Since the poorest countries grow at approximately the same rate as the richest, this suggests that the poorest countries are as well. Thus, it seems that intertemporal distortions must play some role in accounting for the poverty of nations. We have gone to the extreme and assumed, for simplicity, that static distortions play no role.

In our model we assume that there is a common rate of technological progress in the world. One interpretation of this assumption is that this common rate is exogenous and unrelated to private decisions. Another interpretation is that the rate of technological progress is determined by private decisions but technologies spill over to the entire world. For example, in Romer's (1986) model, the average capital stock in the economy affects productivity of each firm, and firms take the evolution of the average capital stock as given. Our model is consistent with Romer's model if we interpret this average capital stock as being the average capital stock in the world. Under either of these interpretations this paper is about the economics of development, which we think of as the study of the relative income distribution, and not about the economics of growth, which we think of as the study of improvements in world per-capita output. In this sense our work is complementary to the extensive literature on endogenous growth (see, for example, Grossman and Helpman 1991, Jones and Manuelli 1990, Lucas 1988, Rebelo 1991, Romer 1990, and Stokey 1988.)

We view our contribution as consisting of measuring distortions, incorporating the measured distortions in a general equilibrium model, and asking, in the context of the model, what fraction of the variability in incomes across countries can be accounted for by the measured distortions. In the spirit of Solow's (1970) work we have abstracted from differences in technology across countries. In order to keep the model simple, we have abstracted from other forces that produce variations in relative income, such as terms of trade shocks or business-cycle shocks.

\section{Data Analysis}

Our data are from the Penn World Table, version 5.6. (See Summers and Heston 1991 for a complete description.) These data are a panel of various measures of annual aggregate output 
and its components from 1960 onward for almost all countries. We use the data for the years 1960 through 1985 in our analysis. Our sample consists of the 125 countries for which investment and output-per-worker data are available for every year from 1960 to 1985 . Our measure of the relative wealth of a nation is gross domestic product (GDP) per worker divided by the (geometric) average of gross domestic product per worker. We refer to this measure as relative output or relative income. Our main findings are as follows:

1. There is great disparity in relative income throughout the sample period.

2. Countries in the middle of the world distribution of income show more mobility in relative positions than countries at either extreme.

3. Growth rates in relative income show little persistence, while investment rates show a lot of persistence.

4. There have been development miracles and disasters. The miracle countries have much higher investment-output ratios than the world average, while the disaster countries have much lower investment-output ratios than the world average.

5. Given initial income, investment rates of countries that move up in the world income distribution are higher than those that do not.

6. Countries with high per worker outputs in 1985 have high capital-output ratios in 1985.

Many of these findings are well known in the development literature (see DeLong 1988, Easterly et al. 1993, Maddison 1991, Parente and Prescott 1993, and Quah 1993, for example). While we have focused on relative incomes, we should note that absolute incomes have increased. The geometric average of output per worker grew at an annually compounded rate of 2.3 percent from 1960 to 1985, so that it was 1.8 times as high in 1985 as in 1960. 
We examine three aspects of the dispersion of income. We think of the ratio of the incomes of the richest 5 percent to the poorest 5 percent as capturing the range of the distribution. In each year, we calculate the ratio of the geometric average of the richest 6 countries' incomes relative to the geometric average of the poorest 6 countries and graph this ratio in Figure 1 . This ratio is 32.2 in 1960 and 31.7 in 1985; it reaches its high of 38.3 in 1970 and its low in 1985. The range shows little change. The second aspect of the dispersion is the standard deviation of the logarithm of relative incomes. The standard deviation is 0.97 in 1960, and 1.06 in 1985 . This standard deviation is largest in 1980 at 1.07, and smallest in 1960. This measure shows a modest increase in dispersion.

The histogram of the distribution of relative incomes provides the third aspect of income dispersion. To construct this histogram we place countries into one of six equally spaced bins based on their relative incomes. The first bin consists of all countries with output per worker between $1 / 8$ and $1 / 4$ of world output per worker. The second bin consists of countries with output per worker between $1 / 4$ and $1 / 2$ of world output per worker, and so on. With one exception, there are no countries with outputs per worker less than $1 / 8$ or more than 8 times the world average. (The exception is Ethiopia, which reaches a minimum relative income level of 0.11 in 1979.) Figure 2A displays the histogram for 1960 and Figure 2B displays the histogram for 1985. The histogram shows that mass has moved from the middle to the extremes. In this sense the dispersion has increased.

An important feature of these data is that individual countries changed their positions in the distribution, sometimes dramatically. One way of summarizing the mobility of individual countries is to construct a mobility matrix (displayed in Table 1). The rows of this matrix correspond to relative positions in 1960, and the columns correspond to relative positions in 1985. Each cell gives the fraction of all countries that started at the relative position given by the row and ended up at the relative position given by the column. For example, the entry (0.09) in row 1, column 2 shows that 9 percent of those countries with incomes between $1 / 8$ and $1 / 4$ of the world average in 1960 had incomes between $1 / 4$ and $1 / 2$ of the world average in 1985 . On the left side of the box we give the fraction of countries in each bin in 1960, while on the bottom we give the fraction of 
countries in each bin in 1985. As can be seen, the diagonal elements are largest at the extremes of the distribution. Mobility is, in this sense, highest in the middle of the distribution.

In some interesting work, Quah (1993) estimates a Markov chain on ranks by using fractiles of incomes at each date. There are two differences between our mobility matrix and Quah's Markov chain. First, we do not interpret our mobility matrix as a Markov chain, because relative incomes do not follow a Markov chain in our theoretical framework. Second, we use incomes rather than ranks because our theory suggests that we do.

In Figure 3 we plot the growth rates of relative income from 1973-85 against growth rates of relative income from 1961-72. Clearly, there is no systematic relation between these growth rates. The correlation between these rates is 0.16 . In Figure 4 we plot the average investment-output ratios from 1973-85 against the average investment-output ratio from 1960-72. The correlation between these ratios is 0.84. (See Easterly et al. 1993 for a detailed investigation of the persistence of growth rates and investment-output ratios.)

It is well known that some countries grew at very rapid rates over this time period, while others experienced declines in output per worker. In Table $2 \mathrm{~A}$ we report on statistics for the 10 countries with the highest growth rates in relative incomes. These countries are the miracles. The growth rate of the geometric means of their relative incomes was 3.3 percent. Since world output per worker grew at 2.3 percent, the miracles' growth rates of output per worker averaged 5.6 percent. This table also shows that the geometric mean of the miracles' investment-output ratios was 21.2 percent, which is 7.1 percent higher than the world average investment-output ratio. In 1960, these countries were not substantially richer or poorer than the world average. Table $2 \mathrm{~A}$ shows that the geometric mean of their incomes in 1960 was 68 percent of the world average. Table 2B displays the same statistics for the 10 countries with the lowest growth rates in relative incomes. These countries are the disasters. The growth rate of the geometric means of the disasters' relative incomes was -3.0 percent; their growth rates of output per worker averaged -0.7 percent. The disasters' investment-output ratios were 8.7 percent lower than the world average. These countries 
were also predominantly in the middle of the income distribution in 1960. Remarkably, the geometric mean of their incomes in 1960 was also 68 percent of the world average. This observation reinforces the point that mobility is highest in the middle of the world income distribution. The most rapidly growing countries were neither the richest nor the poorest and the disasters in terms of growth rates were not the poorest nations.

Next, we examine the behavior of the investment-output ratio for the countries in our sample. In Table 3, we report the average investment-output ratios for the countries in each cell of our mobility matrix on relative incomes. For example, the average investment-output ratio for countries that started in the highest relative income bin and ended there is 25.6. The striking feature of this matrix is that for each starting bin the relatively more successful countries have higher investmentoutput ratios.

We now turn to the relationship between output per worker and the capital-output ratio. This aspect of our data analysis is motivated by the implications of standard neoclassical theory. Consider a Cobb-Douglas production function, $Y=K^{\alpha}(A L)^{1-\alpha}$, which we rewrite as

$$
\frac{Y}{L}=A\left(\frac{K}{Y}\right)^{\frac{\alpha}{1-\alpha}}
$$

Let $y_{i}=\log Y_{i} / L_{i}$ denote the output per worker in country $i$, and let $k_{i}=\log K_{i} / Y_{i}$ denote the capital-output ratio in country $i$. Under the assumption that the technology parameter $A$ is the same in all countries, (1) can be written as

$$
y_{i}-\bar{y}=\frac{\alpha}{1-\alpha}\left(k_{i}-\bar{k}\right)
$$

where $\bar{y}$ is the average of $y_{i}$ and $\bar{k}$ is the average of $k_{i}$. Standard neoclassical theory thus leads us to expect that higher capital-output ratios should be associated with higher levels of output per worker. To see how well the theory works, we must construct estimates of the capital stock in each country. We use the standard perpetual inventory method, which uses data on investment, an initial capital stock, and a depreciation rate to estimate capital stocks. This method uses the law of motion for capital accumulation given by $K_{t+1}=(1-\delta) K_{t}+X_{t}$, where $K_{t}$ denotes the capital 
stock at date $t, X_{t}$ denotes investment at date $t$, and $\delta$ is the depreciation rate. For our investment series we use real investment in 1985 international prices from the Penn World Table.

For our benchmark calculation we choose a depreciation rate of 6 percent. We choose the initial capital stock so that the capital-output ratio in 1960 equals the capital-output ratio in 1985. Note that this way of estimating the final capital stock is a good approximation if the economy is roughly on a balanced growth path. Alternative ways of choosing the initial capital stock yield similar estimates of the final capital stock. For example, we also set the initial capital-output ratio equal to $X / Y /(n+g+\delta)$, where $X / Y$ is the average investment-output ratio from 1960 to 1965 , $n$ is the average rate of growth of the workforce over the same period, $g$ is the common world rate of technical change (2.3 percent per year), and $\delta$ is the depreciation rate (6 percent per year). This way of choosing the initial capital stock would be exactly correct if each country had been on a balanced growth path before 1965. We found that the two procedures yielded similar estimates.

For our sample, the correlation between the logarithm of the constructed capital-output ratio and the logarithm of the output per worker is 0.70. In Figure 5, we plot the left-hand side of (2) against the right-hand side of this equation for $\alpha=1 / 3,2 / 3$, and 0.9 respectively. Inspection of this figure reveals that for $\alpha=2 / 3$ the observations cluster around the 45 degree line. For $\alpha=1 / 3$ or 0.9 , the observations tend to be quite far from the 45 degree line. Since physical capital shares of $2 / 3$ are extremely high, these findings suggest that we should interpret the capital stock in this model as including other types of capital, such as human capital, business capital, and organization capital.

King and Levine (1994) use a similar procedure for estimating the capital stock and obtain capital-output ratios similar to ours. Mankiw, Romer, and Weil (1992) arrive at conclusions similar to ours using a different methodology. They regress the logarithm of GDP per working-age person in 1985 on $X / Y$ and $(n+g+\delta)$, where $X / Y$ is the average investment rate, $n$ is the growth rate of the country's population, $g$ is the common rate of technical change, and $\delta$ is the depreciation rate. They obtain a high $R^{2}$, and their preferred estimate of $\alpha$ is $2 / 3$. The reason that our preferred estimates 
of $\alpha$ are the same as those of Mankiw, Romer, and Weil is that their right-hand side variable is exactly the capital-output ratio along a balanced growth path, and this variable is a good estimate of the capital-output ratio as long as the economy is not too far from such a path.

Other authors have used different methods to obtain a measure for the capital share. Barro and Sala-i-Martin (1995) and others regress growth rates of output per worker on a variety of variables, including the level of initial income. They use linearized transition dynamics to interpret the coefficient on initial income to obtain a measure of capital share. Their preferred estimate for capital share is 0.75. Parente and Prescott (1994) account for postwar Japanese economic performance using a model with both physical capital and business capital. Their preferred estimate for the share of income accruing to broadly measured capital is 0.71 .

Several authors, including Young (1994), have discussed the large changes in labor force participation rates among some of the East Asian tigers. We computed these rates for the countries in our sample. We found a large upward trend in Hong Kong, Korea, and Singapore, as noted by Young. However, several of the other miracles, such as Botswana, Jordan, and Lesotho, have clear downward trends. Overall, we found virtually no difference between the average participation rate of the miracles and the average participation rate of the disasters. (Details available upon request.)

\section{The Economy}

Consider the following economy. There is a single final good which is produced using labor and two capital goods called physical and organization capital. The resource constraint defined over economy-wide aggregates is

$$
C_{t}+X_{k t}+X_{h t} \leq F\left(K_{t}, H_{t}, A_{t} L_{t}\right)
$$

Here $F$ is a constant returns to scale production function $C_{t}$ is consumption, $X_{k t}$ is investment in physical capital, $X_{h t}$ is investment in organization capital, $K_{t}$ is physical capital, $H_{t}$ is organization capital, $L_{t}$ is the exogenously given labor force, and $A_{t}$ is a labor-augmenting technology parameter. For ease of exposition we abstract from growth in labor and in technology by setting $A_{t}=L_{t}=1$. 
In our computations we allow for growth in both, as described below.

The laws of motion for physical and organization capital are given by

$$
\begin{aligned}
& K_{t+1}=X_{k t}+\left(1-\delta_{k}\right) K_{t} \\
& H_{t+1}=X_{h t}+\left(1-\delta_{h}\right) H_{t},
\end{aligned}
$$

where $\delta_{k}$ are the $\delta_{h}$ are the depreciation rates for physical and organization capital, respectively.

Competitive firms rent both types of capital and labor to maximize profits given by

$\max F\left(K_{t}, H_{t}, L_{t}\right)-w_{t} L_{t}-r_{k t} K_{t}-r_{h t} H_{t}$,

where $w_{t}, r_{k t}$, and $r_{h t}$ denote the rental rates on the three types of inputs. In our quantitative analysis we will assume that the production function is Cobb-Douglas so that $F(K, H, L)=$ $K^{\alpha_{k}} H^{\alpha_{h}} L^{1-\alpha_{k}-\alpha_{h}}$.

We need to make a distinction between a representative household's choices and aggregates. We let lower case letters, like $c_{t}$ and $k_{t}$, denote individual household choices. The preferences of the representative, infinitely-lived household are given by the expected utility function

$$
E_{0} \sum_{t=0}^{\infty} \beta^{t} U\left(c_{t}\right),
$$

where $U(c)=c^{1-\sigma} /(1-\sigma)$. The endowment of labor per person is normalized to 1 . The budget constraint of the representative household is given by

$$
c_{t}+\left(1+\theta_{t}\right)\left(x_{k t}+x_{h t}\right) \leq w_{t}+r_{k t} k_{t}+r_{h t} h_{t}+T_{t}
$$

where $\theta_{t}$ represents distortions affecting capital accumulation and $T_{t}$ is transfers. The distortions follow a stochastic process described below. The analogues of (3) and (4) also hold. In equilibrium

$$
T_{t}=\theta_{t}\left(x_{k t}+x_{h t}\right)
$$

These distortions act like a proportional tax on investment which is lump-sum rebated to households. They are meant to capture the disincentives to investment arising from corruption, 
inefficient bureaucracies, and resistance to technology adoption. These obstacles to development have been emphasized by many authors. The simplest interpretation of these distortions is as bribes that have to be paid to undertake investments. Note that we have assumed that these bribes are proportional to the scale of the investment. It seems natural to suppose that larger investment projects require larger bribes and the proportionality assumption is a convenient starting point. Under this interpretation bribes are simply transfers from one agent to another and $T_{t}$ is the value of these transfers. Another interpretation is that special interests block the adoption of new technologies and must be bought off. Since new technologies are often embodied in new investment goods, distortions on investment goods are one measure of the resistance to technology adoption. Under any of these interpretations, if firms are paying the bribes or bearing the costs of overcoming the resistance to technology adoption, consumers simply see higher prices for investment goods than for consumption goods. Letting $p_{t}$ denote the relative price of investment goods, it is clear that in our model $p_{t}=1+\theta_{t}$.

Distortions to investment decisions can sometimes waste resources. It is possible to capture such distortions in a version of our model by simply assuming the proceeds from distortions are not rebated at all. Technically, the only changes to the model are that $T_{t}=0$ and the resource constraint is given by

$$
C_{t}+\left(1+\theta_{t}\right)\left(X_{k t}+X_{h t}\right) \leq F\left(K_{t}, H_{t}, A_{t} L_{t}\right)
$$

We discuss some results for this wasted resources version as well as for our benchmark version below.

The only uncertainty in this economy is about distortions. There are two regimes for distortions: a persistent regime and a turbulent regime. (Our use of these terms is driven by our empirical findings in Section 4.) We let $R \in\{P, T\}$ denote persistent and turbulent regimes. The regime of the economy switches according to an exogenous stochastic process. The probability of a regime switch is a function of the number of periods since the last switch. Let $\pi_{P T}(\tau)$ denote the probability 
of switching from the persistent regime to the turbulent regime, given that the persistent regime has lasted $\tau$ periods. Let $\pi_{T P}(\tau)$ denote the corresponding probability of a switch from a turbulent regime to a persistent regime. Conditional on being in regime $R$, we assume that the distortions follow an autoregressive process given by

$$
\left(1+\theta_{t+1}\right)=\rho_{R}\left(1+\theta_{t}\right)+\mu_{R}\left(1-\rho_{R}\right)+\sigma_{R} \varepsilon_{t+1}
$$

where $\varepsilon_{t}$ is i.i.d. and is drawn from a standard normal distribution. Note that the state of the distortions is described by a triple $(\theta, R, \tau)$.

We now develop a recursive competitive equilibrium. Let $S=(\theta, R, \tau, K, H)$ denote the aggregate state of the economy and $s=(k, h)$ denote the state of a representative household. The household's problem is to choose nonnegative values for $c, x_{k}, x_{h}, k^{\prime}$ and $h^{\prime}$ to solve

$$
v(s, S)=\max \left\{U(c)+\beta E\left[v\left(s^{\prime}, S^{\prime}\right) \mid S\right]\right\}
$$

subject to $k^{\prime}=x_{k}+\left(1-\delta_{k}\right) k, h^{\prime}=x_{h}+\left(1-\delta_{h}\right) h$, and

$$
c+(1+\theta)\left(x_{k}+x_{h}\right)=w(S)+r_{k}(S) k+r_{h}(S) h+T(S)
$$

where, if $S=(\theta, P, \tau, K, H)$ and no regime switch occurs $S^{\prime}=\left(\theta^{\prime}, P, \tau+1, K^{\prime}(S), H^{\prime}(S)\right)$ and $\theta^{\prime}$ is determined by (5) with $R=P$. If a switch occurs then $S^{\prime}=\left(\theta^{\prime}, T, 1, K^{\prime}(S), H^{\prime}(S)\right)$ and $\theta^{\prime}$ is determined by (5) with $R=T$. The analogous relations hold for $R=T$. In (6), w(S), $r_{k}(S)$, and $r_{h}(S)$ denote the rental-rate functions for the three inputs. The aggregate capital stocks evolve according to the aggregate allocation functions $K^{\prime}=K^{\prime}(S)$ and $H^{\prime}=H^{\prime}(S)$. The household's problem yields allocations for its choice variables as functions of $(s, S)$. For example, the allocation function for consumption is given by $c(s, S)$.

A recursive competitive equilibrium is a value function for the household, household allocation functions, aggregate allocation functions, and rental-rate functions which satisfy the following conditions: (i) the value function and the household allocation functions solve (6), (ii) the rentalrate functions satisfy: $w(S)=F_{L}(K, H, 1), r_{k}(S)=F_{K}(K, H, 1), r_{h}(S)=F_{H}(K, H, 1)$, and (iii) 
the household and aggregate allocations satisfy the market-clearing conditions: $k^{\prime}(S, S)=K^{\prime}(S)$, $h^{\prime}(S, S)=H^{\prime}(S)$ and $c(S, S)+x_{k}(S, S)+x_{h}(S, S)=F(K, H, 1)$.

To gain some intuition for the properties of this model, consider a deterministic economy with a distortion level $\theta$ in which the production function is given by $F(K, H, L)=K^{\alpha_{k}} H^{\alpha_{h}}(A L)^{1-\alpha_{k}-\alpha_{h}}$ and $\delta_{h}=\delta_{k}=\delta$. In the steady state the consumer's first-order conditions imply

$$
\begin{aligned}
& 1=\beta\left[\frac{\alpha_{k} Y / K}{1+\theta}+1-\delta\right] \\
& 1=\beta\left[\frac{\alpha_{h} Y / H}{1+\theta}+1-\delta\right] .
\end{aligned}
$$

Consider two economies which have distortions $\theta$ and $\theta^{\prime}$, respectively. Let $y(\theta)$ and $y\left(\theta^{\prime}\right)$ denote output per worker in the two economies. Using the form of the production function given above we obtain

$$
\frac{y(\theta)}{y\left(\theta^{\prime}\right)}=\left[\frac{1+\theta^{\prime}}{1+\theta}\right]^{\left(\alpha_{k}+\alpha_{h}\right) /\left(1-\alpha_{k}-\alpha_{h}\right)} .
$$

It is clear from (9) that what matters for determining two countries' relative incomes is the ratio of the gross distortions $\left(1+\theta^{\prime}\right) /(1+\theta)$. For concreteness, suppose $\theta=0$ and $\alpha_{k}=\alpha_{h}=1 / 3$. If the distortion $1+\theta^{\prime}$ in the distorted economy is 4 , then the income of the undistorted economy is $16\left(=4^{2}\right)$ times that of the distorted economy. It should be clear from (9) that the larger the total capital share $\alpha_{k}+\alpha_{h}$, the greater the magnification of distortions on relative income. For example, if $\alpha_{k}+\alpha_{h}=3 / 4$, then a relative distortion of 4 gives relative incomes of $64\left(=4^{3}\right)$.

Equations (7) and (8) also show one feature of our model worth emphasizing. Capitaloutput ratios in a steady state do not depend on the technology parameter $A$. This feature of the model means that differences in technology across countries do not lead, at least in a steady state, to differences in capital-output ratios. In the data we see that the growth rates of the poorest countries are similar to that of the richest countries. The richest countries are typically characterized as being on a balanced growth suggesting that the poorest countries are as well. In the data we see large differences in capital-output ratios between the richest and poorest countries. To the extent that a 
Cobb-Douglas production function is a good approximation then, the data suggests that there must be some intertemporal distortion that differs systematically across countries.

In our computations we assume that the technology parameter grows according to $A_{t+1}=$ $(1+g) A_{t}$, and that the labor force evolves according to $L_{t+1}=(1+n) L_{t}$. The representative household maximizes the discounted utility of its growing family. If we express the household variables as amounts per effective person, the problem of the household is the same as the above,

except that the discount factor is now $\beta(1+n)(1+g)^{1-\sigma}$ and the laws of motion for the capital stocks of the representative household become

$$
\begin{aligned}
& (1+g)(1+n) k^{\prime}=x_{k}+\left(1-\delta_{k}\right) k, \\
& (1+g)(1+n) h^{\prime}=x_{h}+\left(1-\delta_{h}\right) h .
\end{aligned}
$$

We also set the depreciation rates for physical and organizational capital equal to each other. This implies that we need only record the total capital stock $k+h$ in the state vector.

\section{Measuring Distortions}

In this section we describe how we measure distortions, how we estimate a stochastic process for them, and we discuss potential biases in our measure of distortions. The stand we take is that the relative price of investment goods to consumption goods is a measure of the distortions. We calculate the relative price of investment goods to consumption goods for each country and each year in our sample using the data in Summers and Heston (1991).

Before we turn to the formal estimation we report some summary statistics. For each country we compute the average over time of its relative price. The mean across countries of the average relative price is 1.78 . The cross-country standard deviation of the average relative price is 1.18 . We measure the range as follows. We select the $5 \%$ of the countries with the highest average relative price and the $5 \%$ with the lowest average relative price. The ratio of the averages of the highest to the lowest is 7.48 . 


\subsection{Estimating the stochastic process for distortions}

We use a regime switching model (see Hamilton 1994) in which we allow the probability of switching regimes to depend on the number of periods the economy has been in the regime. There are two regimes $R=P, T$, referred to as the persistent and the turbulent regime, respectively. Conditional on being in regime $R$, we assume that the distortions follow an autoregressive process given by (5). We assume that the probability of switching from the persistent regime to the turbulent regime, conditional on having been in the persistent regime for $\tau$ periods is given by a piecewise linear function of the form

$$
\pi_{P T}(\tau)=a_{P}-b_{P}(\tau-1)
$$

if $\tau \leq 20$, and $\pi_{P T}(\tau)=a_{P}-b_{P}(19)$ if $\tau \geq 20$, where $a_{P}$ and $b_{P}$ are parameters. The probability of switching from the turbulent regime to the persistent regime is similarly described by

$$
\pi_{T P}(\tau)=a_{T}-b_{T}(\tau-1)
$$

if $\tau \leq 20$, and $\pi_{T P}(\tau)=a_{T}-b_{T}(19)$ if $\tau \geq 20$, where $a_{T}$ and $b_{T}$ are parameters.

The parameters of our stochastic process are $\gamma=\left(\mu_{R}, \rho_{R}, \sigma_{R}, a_{R}, b_{R} \mid R=P, T\right)$. We estimate these parameters by maximum likelihood. Our procedure is an extension of that in Hamilton (1994) and is described in more detail in Appendix 1. We use the Summers and Heston (1991) measures of the relative prices of investment and consumption goods as our measure of the distortions.

In Table 4, we report maximum likelihood estimates for our parameters along with standard errors. Note that, conditional on being in regime $R=P$, the process is persistent. The coefficient on the lagged relative price is 0.993 and the standard deviation of the innovation is 0.074 . Conditional on being in regime $R=T$, the coefficient on the lagged relative price is 0.865 and the standard deviation of the innovation is 0.789 . The unconditional variance of the relative price is 2.47 in the turbulent regime and 0.39 in persistent regime. Thus the relative price fluctuates a lot more in the turbulent regime than it does in the persistent regime. Notice that in the turbulent regime relative prices show more mean reversion than in the persistent regime. Table 4 also shows that 
the unconditional mean of the relative price is 2 in the persistent regime and 2.5 in the turbulent regime.

The parameters of the switching probability functions are reported in Table 4. The probability of switching from the persistent to the turbulent regime, conditional on having switched to the persistent regime in the previous period, is 0.24 while this probability is 0.016 conditional on having been in the persistent regime for 20 periods or more. The probability of switching from the turbulent to the persistent regime, conditional on having switched to the turbulent regime in the previous period, is 0.35 , while this probability is 0.046 conditional on having been in the turbulent regime for 20 periods or more. Thus, the probability of leaving the persistent regime is lower than the probability of leaving the turbulent regime. Notice the turbulent regime is aptly named because of two characteristics: conditional in being in the regime, relative prices fluctuate more and the probability of leaving the regime is higher. In Table 4 we also report the standard errors associated with the maximum likelihood estimates of our parameters. These standard errors show that all of our parameters are estimated fairly precisely.

We tested several hypotheses. First, we tested the hypothesis that $b_{P}=b_{T}=0$; that is, the probability of switching regimes does not depend on the number of years in a regime. Using a likelihood ratio test we rejected this hypothesis at the $0.1 \%$ level. (The test statistic is $\chi^{2}(2)$ =121.72.) We also tested the hypothesis that there is only one regime. With one regime, the regime switching parameters are nuisance parameters. Therefore, we simply set them equal to the estimates reported in Table 4 and tested the hypothesis: $\mu_{P}=\mu_{T}, \rho_{P}=\rho_{T}$, and $\sigma_{P}=\sigma_{T}$. Using a likelihood ratio test we reject this hypothesis at the $0.1 \%$ level. (The test statistic is $\chi^{2}(3)=5690$.) We experimented with other functional forms for the switching probabilities, such as piecewise linear with multiple breaks and quadratic functions. We also experimented with three regimes. None of these modifications substantially improved the fit of the model. 


\subsection{Potential biases}

One concern over the use of relative prices to measure distortions stems from the following argument. Suppose consumption goods are largely nontraded labor intensive services. In this case, we would expect from the trade literature (see Kravis and Lipsey 1988) that consumption goods would be systematically cheaper in capital poor countries. Then the relative price overestimates the distortions. In this section we provide two arguments to show that this sort of bias is unlikely to be large.

The first argument has to do with differing capital intensities for producing consumption and investment goods. One interpretation of our model is that there are two sectors with identical production functions for producing consumption and investment goods. Under this assumption, the distortions are simply the relative price of investment goods to consumption goods. If investment goods production is more capital intensive than consumption goods production we would expect that capital poor countries would have higher relative prices of investment goods even if there are no distortions. On the other hand, if investment goods production is more labor intensive than consumption goods production, the opposite is true.

Consider the following example to illustrate the effect of capital intensities on the relative price of investment goods. In this example there is only one type of capital and both production functions are Cobb-Douglas. Specifically the technologies are $C=K_{c}^{\alpha} L_{c}^{1-\alpha}$ and $X=K_{x}^{\gamma} L_{x}^{1-\gamma}$. The aggregate capital stock is given by $K=K_{c}+K_{x}$ and the aggregate labor input by $L=L_{c}+L_{x}$. Capital accumulation follows $K_{t+1}=(1-\delta) K_{t}+X_{t}$. A representative household has preferences given by $\sum \beta^{t} U\left(c_{t}\right)$. A competitive equilibrium with distortions is defined in the usual fashion. The steady state conditions are

(11) $\frac{1-\alpha}{\alpha} \frac{K_{c}}{L_{c}}=\frac{1-\gamma}{\gamma} \frac{K_{x}}{L_{x}}$

$$
\frac{p}{(1+\theta)}(1-\gamma)\left(\frac{K_{x}}{L_{x}}\right)^{\gamma}=(1-\alpha)\left(\frac{K_{c}}{L_{c}}\right)^{\alpha}
$$


where $p$ denotes the relative price of investment to consumption goods. Consider a set of economies indexed by $\theta$. Equations (10), (11), and (12) can be combined to yield $p=A(1+\theta)^{\frac{1-\alpha}{1-\gamma}}$, where $A$ is a constant that is the same across countries. Consider two economies with distortions $\theta_{1}$ and $\theta_{2}$, where $\theta_{1}<\theta_{2}$, and relative prices $p_{1}$ and $p_{2}$. If $\gamma>\alpha$ then

$$
\frac{p_{2}}{p_{1}}>\frac{1+\theta_{2}}{1+\theta_{1}}
$$

while if $\gamma<\alpha$ then the inequality is reversed. That is, if investment goods production is more capital intensive than consumption goods production $(\gamma>\alpha)$, using relative prices as a measure of distortions overstates the true variability in distortions across countries. The reverse is true if $\alpha>\gamma$

Clearly, which sector is more capital intensive is an empirical issue. To shed light on this question we constructed measures of capital intensities for the United States and Mexico using inputoutput tables for the two countries. (For the United States we used the Survey of Current Business 1994, and for Mexico we used data from the National Statistics Institute, INEGI, Instituto Nacional de Estadística, Geographia, i Informática.) The input-output tables provide data on the values of commodities sold by each industry, purchased by each industry, and sold to final demand sectors. These final demand sectors include personal consumption expenditures, investment expenditures, the foreign trade sector, and the government sector. The tables also provide data on labor share relative to value added for each industry. We use these tables to compute labor share associated with the production of consumption expenditures on consumption and on investment. The details of the procedure are described in Appendix 2. Using this procedure we estimate that the capital shares in the consumption and the investment goods sectors for the United States are $\alpha=0.39$ and $\gamma$ $=0.31$, respectively. We were concerned that the higher capital intensity in the consumption sector was due to the fact that housing services are very capital intensive. Removing housing, however, did not change the ranking of capital intensities. (Removing owner-occupied dwellings yields $\alpha=0.34$ and $\gamma=0.31$.) Our estimates for the capital shares in the consumption and the investment goods 
sectors for Mexico are $\alpha=0.79$ and $\gamma=0.68$, respectively. This evidence leads us to conclude that the use of relative prices leads, if anything, to an underestimate of the true distortions.

A second issue that concerned us was that the relative price of investment goods to consumption goods is systematically higher in poor countries merely because consumption goods are cheap in poor countries. Summers and Heston (1991) report the prices of investment and consumption goods in each country relative to a world basket. For each country we computed the average price for investment goods relative to the world basket of investment goods and the average price of investment goods relative to consumption goods in that country. We computed the average price for investment goods for the 6 countries with the highest investment goods prices and the 6 countries with the lowest investment goods prices. We use the ratio of the highest to the lowest as a measure of the range of the distribution of the relative price of investment goods. The ratio of the relative prices of investment goods to consumption goods is 7.48 for the countries in our sample. We computed a similar ratio for the price of investment goods relative to the world price for a basket of investment goods and obtained 5.82. We interpret this evidence as suggesting that the variation in investment goods prices is significant by itself. One source of this variation is distortions. In any event, we do not attempt in this paper to account for the systematic differences in national price levels seen in the data.

\section{Calibration and Measurement Issues}

In this section we calibrate the parameters of preferences, technology, and policy. We list the values of these parameters in Table 4 . The preference parameters $\beta$ and $\sigma$ are standard in the real business-cycle literature (see, for example, Chari, Christiano, and Kehoe 1994 or McGrattan 1994). We set the technology parameters $\alpha_{k}, \delta_{k}, g$, and $n$ as in the real business-cycle literature, and we set $\delta_{h}=\delta_{k}$.

As we showed in the data section, there is evidence for a broad capital share of roughly $2 / 3$, which implies that $\alpha_{h}=1 / 3$. We also use an argument of Mankiw, Romer, and Weil (1992) 
to support this choice of $\alpha_{h}$. In the model, for a person with no given human capital, the total compensation for $L$ units of labor services is $w L$. The compensation for $L$ units of labor services and $H$ units of human capital services is $w L+r_{h} H$. Profit maximization implies that the wage premium is given by

$$
\frac{w L+r_{h} H}{w L}=\frac{\left(1-\alpha_{k}-\alpha_{h}\right) Y+\alpha_{h} Y}{\left(1-\alpha_{k}-\alpha_{h}\right) Y}=\frac{\left(1-\alpha_{k}\right)}{\left(1-\alpha_{k}-\alpha_{h}\right)}
$$

Mankiw, Romer, and Weil measure the wage premium in the United States. They assume the minimum wage is the wage paid to a person with zero human capital. They report that in the United States the ratio of the wage paid to the average worker to the minimum wage is approximately 2 . Using this as a measure of the wage premium in (13) and assuming that $\alpha_{k}=1 / 3$ implies $\alpha_{h}=1 / 3$.

We turn next to two measurement issues. Both issues involve measuring GDP in our model so as to make it comparable to GDP as measured by Summers and Heston (1991). These authors measure GDP for a country by multiplying the quantities of consumption and investment goods in a country by a common set of world prices. In the context of our model we first assume that the world prices of consumption and investment goods are one. Second, we assume that the organization capital accumulation described in our model occurs in the workplace. The national income accounts do not include organization capital investment of this kind in measures of investment. Under these assumptions our measure of GDP is given by $y_{t}=c_{t}+x_{k t}$.

\section{Findings}

In this section we report our findings for the model. All the statistics we compute come from realizations of 125 countries, with initial conditions set to mimic the 1960 income distribution and the initial policies set in accordance with our model. We find that the model does a fairly good job on many of the statistics.

We begin by describing the initial states. In order to simulate the model we first choose initial states $(\theta, R, \tau, k+h)$ for 125 countries. Our model implies a stationary joint distribution over $(\theta, R, \tau, r y)$, where $r y$ denotes relative income and is given by the ratio of a country's income 
to its geometric mean across countries. We use this joint distribution to construct the conditional distribution of $(\theta, R, \tau)$ given $r y$. We set initial conditions for $r y$ to be the same as in the data and choose $(\theta, R, \tau)$ from the corresponding conditional distribution. Given these initial conditions, we then simulate all 125 countries for 26 periods and calculate various statistics. We repeat this procedure 100 times. In what follows we focus on both statistics from a single simulation and on averages across the 100 simulations.

We begin with the range of the distribution of incomes which is the ratio of the relative incomes of the richest 5 percent to the poorest 5 percent. We calculate the average over time for each simulation and find that the range in our model is similar to that in the data. The average disparity across simulations is 33.8 (with a standard deviation of 0.67 ) while the average disparity in the data is 34.5. As in the data, the range of the distribution shows little change over time. Next, we computed the standard deviation of the logarithm of relative incomes. As in the data, the standard deviation increases from 1960 to 1985. The mean of the standard deviation across simulations in 1985 is 0.94 (with a standard deviation of 0.022 ). Recall that the standard deviation in 1985 in the data is 1.06 . Thus, the ratio of the variance of incomes in the model to the variance of incomes in 1985 in the data is 0.79 (with a standard deviation of 0.037 ). In this sense our model accounts for $79 \%$ of the variability in relative incomes across countries in $1985 .^{1}$

In Table 5 we report the means across simulations of the 25 -period mobility matrix. The numbers in parentheses denote standard deviations across simulations. This matrix shares some features with the analogous matrix in the data. Consider the diagonal elements which measure the fraction of countries that stay in their original relative positions. The very poor and the very rich countries are more likely to stay in their relative position than countries in the middle of the income distribution. That is, both the data and the model show more mobility in the middle than in the

\footnotetext{
${ }^{1}$ We prefer the ratio of the variances rather than the ratio of the standard deviations for the following reason. If two factors $x$ and $z$ contribute to the variance of $y$, then with independence, the variance of $y$ is the sum of the variances of $x$ and $z$. It then makes sense to say that factor $x$ accounts for a given fraction of the variation in $y$ and factor $z$ accounts for the remainder.
} 
extremes. A minor problem is that the rich, the near rich, and the very poor show more mobility in the model than in the data.

Using data from a single simulation, in Figure 6 we plot the growth rates of relative incomes in the last 13 periods against the growth rates in the first 12 periods. (In order to make the range of this figure comparable to that in the figure for the data, Figure 3, we omit one outlier with growth rates of 9.7 and -2.8 in the two subperiods.) Clearly, there is no pattern in the model. The correlation between these variables is 0.17 for this simulation (including the outlier) and the average correlation across simulations is 0.26 , with a standard deviation of 0.10 . The analogous correlation in the data is 0.16 . In Figure 7 we plot the average investment-output ratios in the last 13 periods against the average investment-output ratios in the first 13 periods. (In order to make this figure comparable to the corresponding figure for the data, Figure 4, we omit 3 outliers with investmentoutput ratios exceeding $40 \%$ in either subperiod). Clearly, these are highly positively correlated. The correlation between these variables is 0.85 for this simulation (including the outliers) and the average correlation across simulations is 0.72 with a standard deviation of 0.07 . The analogous correlation in the data is 0.84 .

Consider next the miracles and disasters. Following the same criterion as we did in the data, we dub the 10 fastest growers miracles and the 10 slowest growers disasters. Tables $6 \mathrm{~A}$ and $6 \mathrm{~B}$ report some summary statistics. These tables show that the model can indeed generate miracles and disasters. These miracles and disasters look similar to those in the data. Miracles have higher investment-output ratios than the world average, while disasters have lower investment-output ratios than the world average. In the model the average relative income of the miracles in the first period is close to the corresponding average in the data in 1960. The main difference between the model and the data is that in the model the disasters are, on average, initially richer than the world average, while in the data the disasters are poorer than the world average. As in the data, the miracles and disasters are not the richest or the poorest in the initial period.

In Table 7 we display the mean across simulations of the average investment-output ratios 
for each cell of our mobility matrix. The standard deviations across simulations are reported in parentheses. This matrix, like its analogue in the data, has the feature that for a given starting bin, relatively successful countries have higher investment-output ratios. The main difference is that in the model the investment-output ratios are more dispersed than in the data.

So far we have considered a world in which each country is a closed economy. In it, marginal productivities vary greatly across countries. Lucas (1990) argued that these differences in marginal productivities create incentives for capital to flow from rich to poor countries. In our model there is little incentive for capital to flow from rich to poor countries. To see this, consider a country that has been rich for a long time and one that has been poor for a long time. These countries are close to the deterministic steady states associated with their respective distortions. This implies that the returns to investing in the two countries are close, and thus there is no incentive for capital to flow (see equations 7 and 8).

In our model there is an incentive for capital to flow from potential disasters to the rest of the world and for capital to flow from the rest of the world to the potential miracles. For the miracles, distortions are typically low, and for the disasters, distortions are typically high. Thus expected returns are high in miracles and low in disasters. To get a feel for the magnitudes of these incentives we use the following procedure. We first compute that constant rate of return forever which yields the same present value as the after-tax expected present value of investing in the country (namely, the certainty-equivalent rate of return). One way to get a feel for the variability in the certaintyequivalent rates of return is to consider a world in which there is complete capital mobility, but where countries expropriate the assets of foreigners with a constant probability over time. As a benchmark, consider a country that is on a deterministic, balanced growth path with no distortions. We compute the probability of expropriation for each country associated with these given certaintyequivalent rates of returns as follows. The probabilities are chosen so that investors would be indifferent between investing in the benchmark country and receiving the certainty-equivalent return in each period so long as there has never been an expropriation. We find that these expropriation 
probabilities are fairly modest. The expropriation probabilities are less than $2.5 \%$ for $90 \%$ of the countries in our model, and are less than $4.7 \%$ for $95 \%$ of the countries. There are two outliers, one of which is a miracle with an expropriation probability of $16 \%$ and the other is a near miracle with an expropriation probability of $23 \%$. Of course, investors in potential disasters would like to invest in the rest of the world, but it is easy to imagine that capital controls would prevent them from doing so.

We also computed statistics for the wasted resources version of the model. The results were broadly similar, with two main exceptions. First, in the benchmark model the range of disparity of incomes is roughly constant over time, as it is is in the data, while in the wasted resources model the range of disparity increases from 31 to 44 . Second, the miracles grow more rapidly and the disasters decline more rapidly in the wasted resources model than in the benchmark model.

\section{Conclusion}

Our paper contains two contributions to the development literature in the neoclassical tradition. First, we develop a simple model where an underlying stochastic process common to all countries generates a panel of outcomes which is compared to the data. Second, we use data to measure the distortions. We have argued that the model accounts for a sizeable fraction of the

observed variability in incomes. The model also does well in accounting for patterns in the mobility of income and in accounting for the growth rates of miracles and disasters. There are two main discrepancies between the model and the data. Disasters are substantially richer in the model than in the data and investment-output ratios are more dispersed in the model than in the data.

Our paper suggests two avenues for future research. First, it would be useful to develop direct measures of organization capital. These measures would allow us to distinguish the extent to which countries differ in their factor inputs and in their technology levels. Second, it would be useful to improve on our measures of distortions to correct for the potential biases discussed in Section 4 .

Fluctuations in growth rates in our model are solely driven by stochastic distortions to 
investment. We have abstracted from other forces that produce fluctuations in growth rates in relative income, such as terms-of-trade shocks, business-cycle shocks, or differing rates of technology adoption. Introducing such forces is an important direction for future research. It would also be useful to embed this model in one for which the rate of growth of world technology is determined by private decisions. 


\section{References}

Arrow, Kenneth J. 1962. The economic implications of learning by doing. Review of Economic Studies 29(3), No. 80, 155-73.

Barro, Robert J. 1991. Economic growth in a cross-section of countries. Quarterly Journal of Economics 106(2): 407-443.

Barro, Robert J., and Sala-i-Martin, Xavier. 1995. Economic growth. New York: McGraw-Hill.

Becker, Gary S. 1993. Human capital: a theoretical and empirical analysis, with special reference to education. 3rd ed., Chicago: University of Chicago Press.

Chari, V. V.; Christiano, Lawrence J.; and Kehoe, Patrick J. 1994. Optimal fiscal policy in a business cycle model. Journal of Political Economy 102(4): 617-52.

DeLong, J. Bradford. 1988. Productivity growth, convergence, and welfare: Comment. American Economic Review 78(5): 1138-54.

DeLong, J. Bradford, and Summers, Lawrence H. 1991. Equipment investment and economic growth. Quarterly Journal of Economics 106(2):445-502.

de Soto, Hernando. 1989. The other path: The invisible revolution in the third world. New York: Harper and Row.

Easterly, William. 1993. How much do distortions affect growth? Journal of Monetary Economics $32(2): 187-212$.

Easterly, William; Kremer, Michael; Pritchett, Lant; and Summers, Lawrence H. 1993. Good policy or good luck? Country growth performance and temporary shocks. Journal of Monetary Economics 32(3): 459-83.

Grossman, Gene and Helpman, Elhanan. 1991. Innovation and Growth in the Global Economy. Cambridge, MA: MIT Press.

Hamilton, James D. 1994. Time Series Analysis. Princeton: Princeton University Press.

Jones, Charles I. 1994. Economic growth and the relative price of capital. Journal of Monetary Economics 34(3): 359-82.

Jones, Larry E., and Manuelli, Rodolfo E. 1990. A convex model of equilibrium growth: Theory and policy. Journal of Political Economy 98(5), part 1: 1008-38.

King, Robert G., and Levine, Ross. 1994. Capital fundamentalism, economic development, and economic growth. Carnegie-Rochester Conference Series on Public Policy 40(June): 259-92.

Kravis, Irving, and Lipsey, Robert. 1988. National price levels and the prices of tradables and nontradables. American Economic Review 78(2): 474-78.

Lucas, Robert E., Jr. 1988. On the mechanics of economic development. Journal of Monetary Economics 22(1): 3-42. 
Lucas, Robert E., Jr. 1990. Why doesn't capital flow from rich to poor countries? American Economic Review 80(2): 92-96.

Lucas, Robert E., Jr. 1993. Making a miracle. Econometrica 61(2): 251-72.

Maddison, Angus. 1991. Dynamic forces in capitalist development: A long-run comparative view. New York: Oxford University Press.

Mankiw, N. Gregory; Romer, David; and Weil, David N. 1992. A contribution to the empirics of economic growth. Quarterly Journal of Economics 107(2): 407-37.

McGrattan, Ellen R. 1994. The macroeconomic effects of distortionary taxation. Journal of Monetary Economics 33(3): 573-601.

Parente, Stephen L., and Prescott, Edward C. 1993. Changes in the wealth of nations. Federal Reserve Bank of Minneapolis Quarterly Review 17(2): 3-16.

Parente, Stephen L., and Prescott, Edward C. 1994. Barriers to technology adoption and development. Journal of Political Economy 102(2): 298-321.

Prescott, Edward C., and Boyd, John. 1987. Dynamic coalitions: engines of growth. American Economic Review 77(2): 63-67.

Prescott, Edward C., and Visscher, Michael. 1980. Organization capital. Journal of Political Economy 88(3): 446-61.

Quah, Danny. 1993. Empirical cross-section dynamics in economic growth. European Economic Review 37(April): 426-34.

Rebelo, Sergio. 1991. Long-run policy analysis and long-run growth. Journal of Political Economy. $99(3): 500-521$.

Romer, Paul M. 1986. Increasing returns and long-run growth. Journal of Political Economy 94(5): 1002-37.

Romer, Paul M. 1990. Endogenous technological change. Journal of Political Economy 98(5), part 2: S71-S102.

Rosen, Sherwin. 1972. Learning by experience as joint production. Quarterly Journal of Economics 86(3): $366-82$.

Solow, Robert M. 1970. Growth theory: An exposition. (The Radcliffe Lectures) Oxford: Clarendon Press.

Stokey, Nancy L. 1988. Learning by doing and the introduction of new goods. Journal of Political Economy 96(4): 701-17.

Summers, Robert, and Heston, Alan. 1991. The Penn world table (Mark 5): An expanded set of international comparisons, 1950-1988. Quarterly Journal of Economics 106(2): 327-68.

Young, Alwyn. 1995. The tyranny of numbers: Confronting the statistical realities of the East Asian growth experience. Quarterly Journal of Economics 110(3): 641-80. 
Figure 1. Ratio of the Relative Incomes of the Rich and Poor in the Data

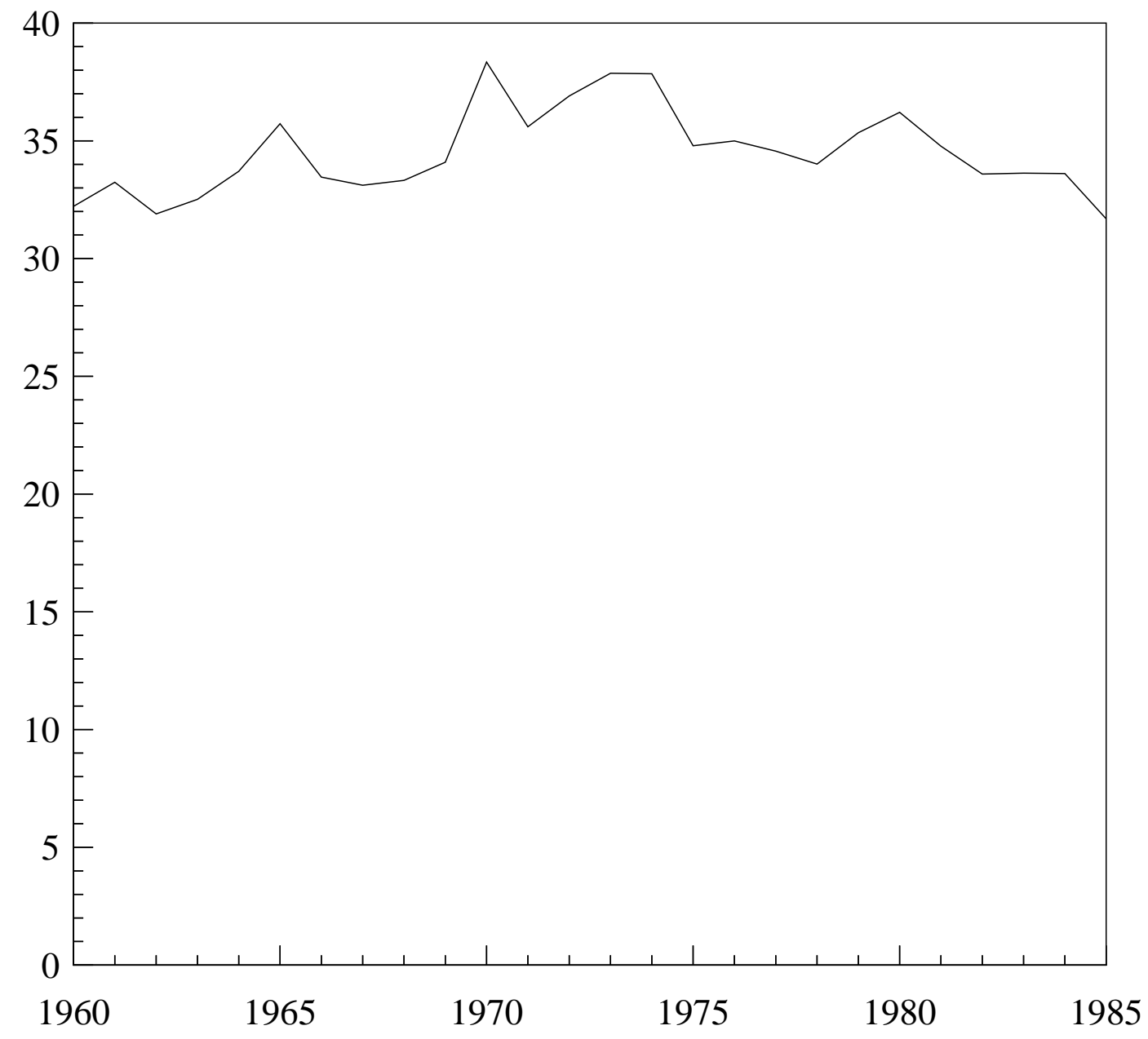


Figure 2A. Histogram of Relative Incomes for 1960 in the Data

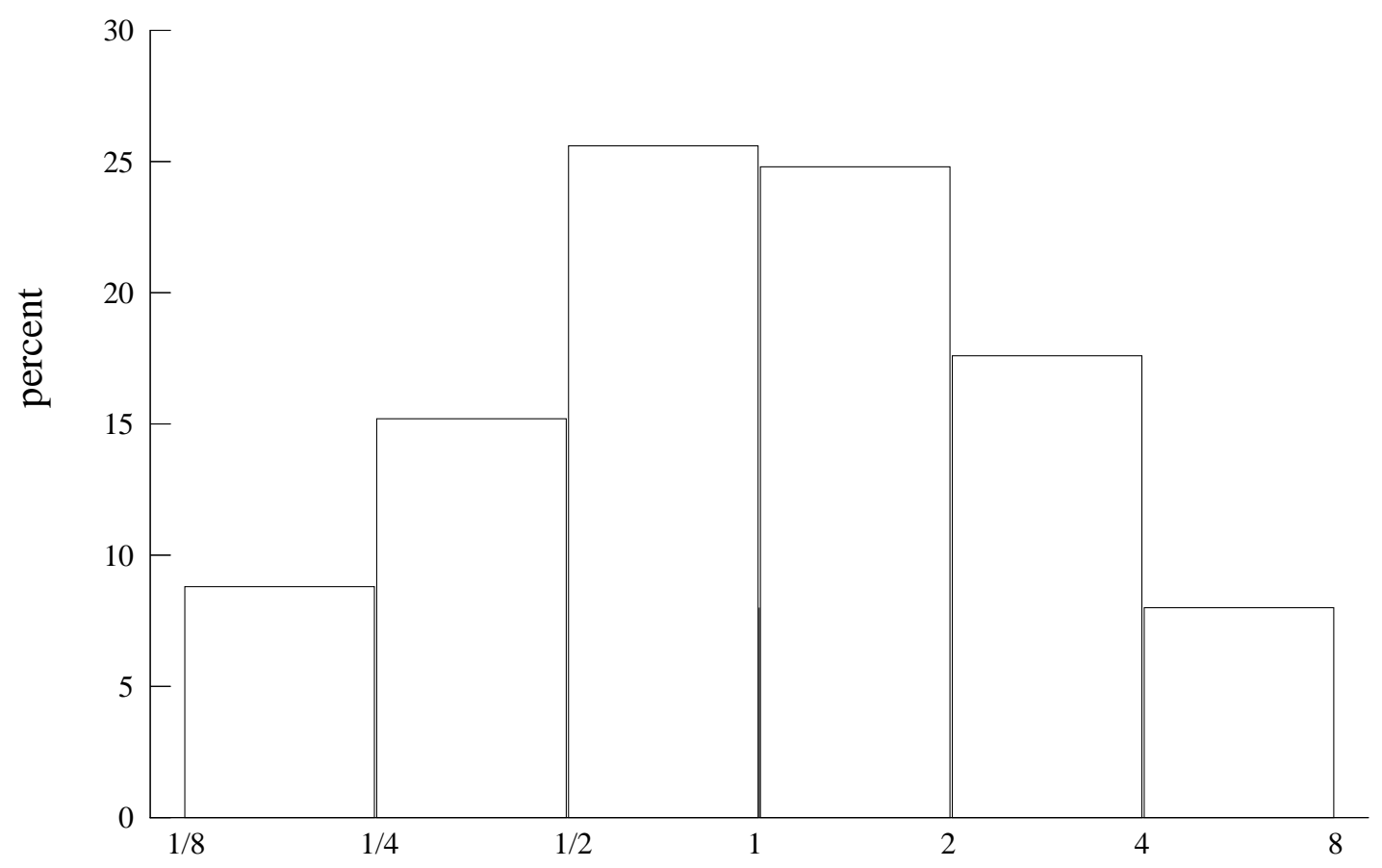

Figure 2B. Histogram of Relative Incomes for 1985 in the Data

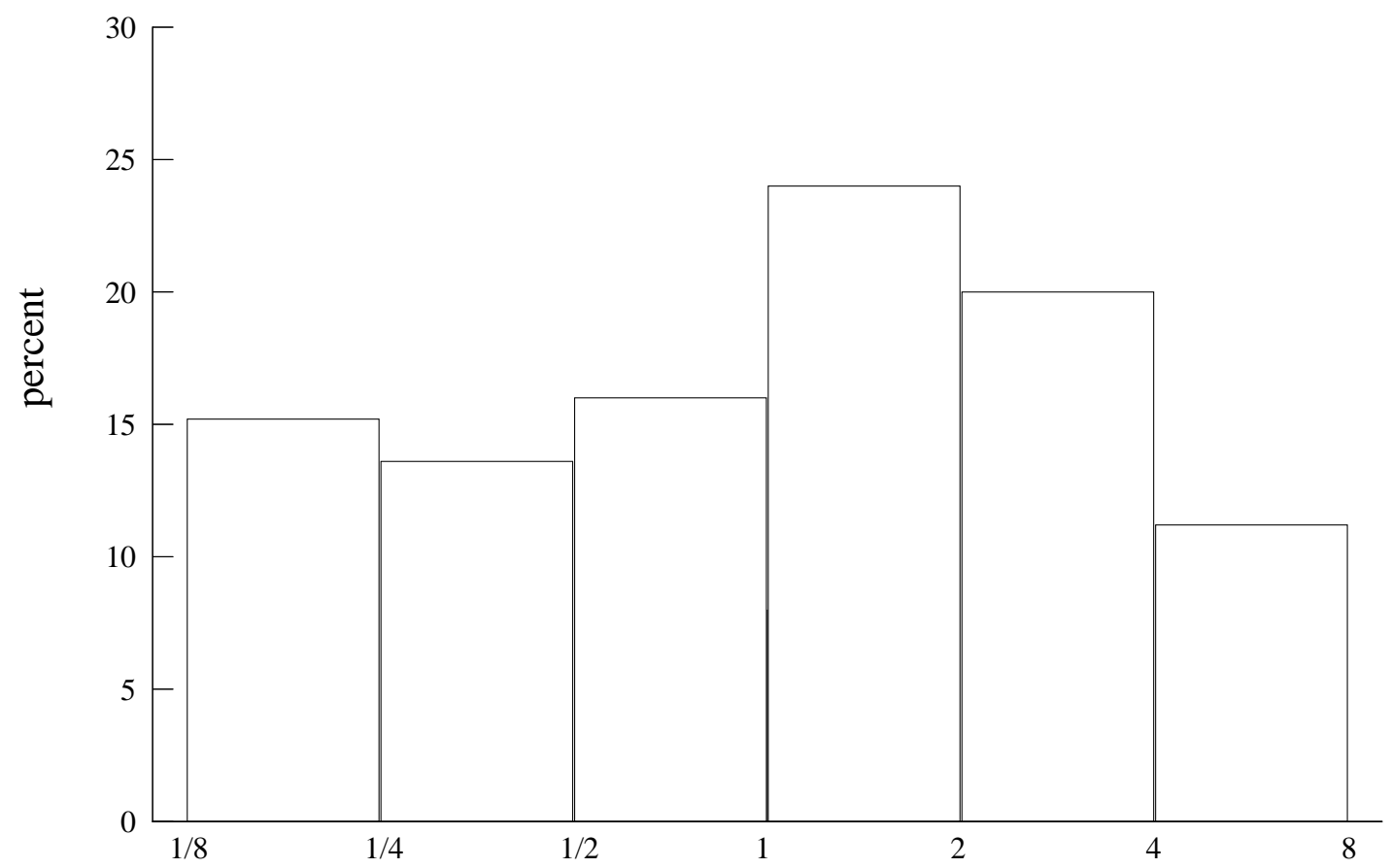


Figure 3. Persistence of Growth Rates in the Data

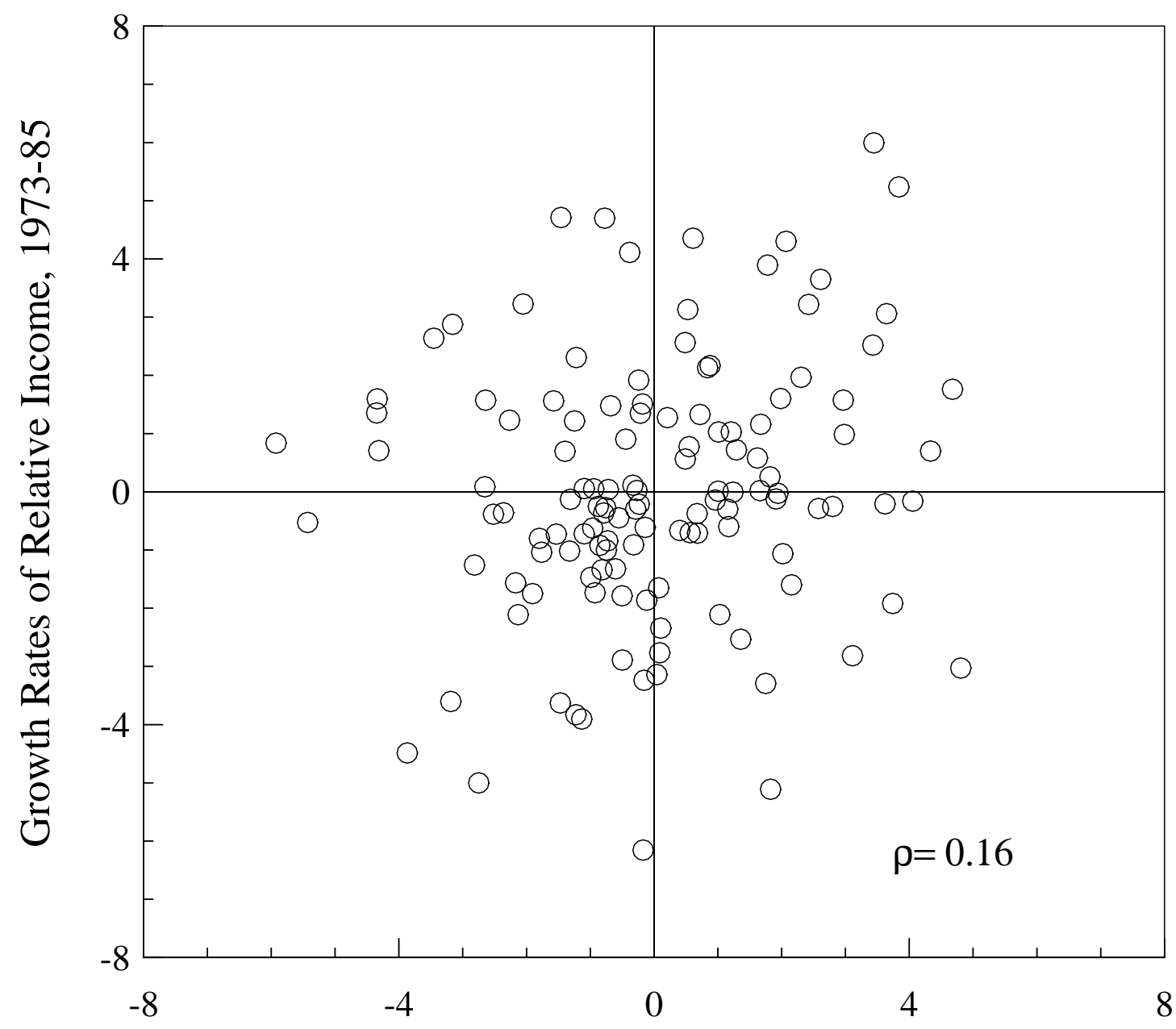

Growth Rates of Relative Income, 1961-72 
Figure 4. Persistence of Investment-Output Ratios in the Data*

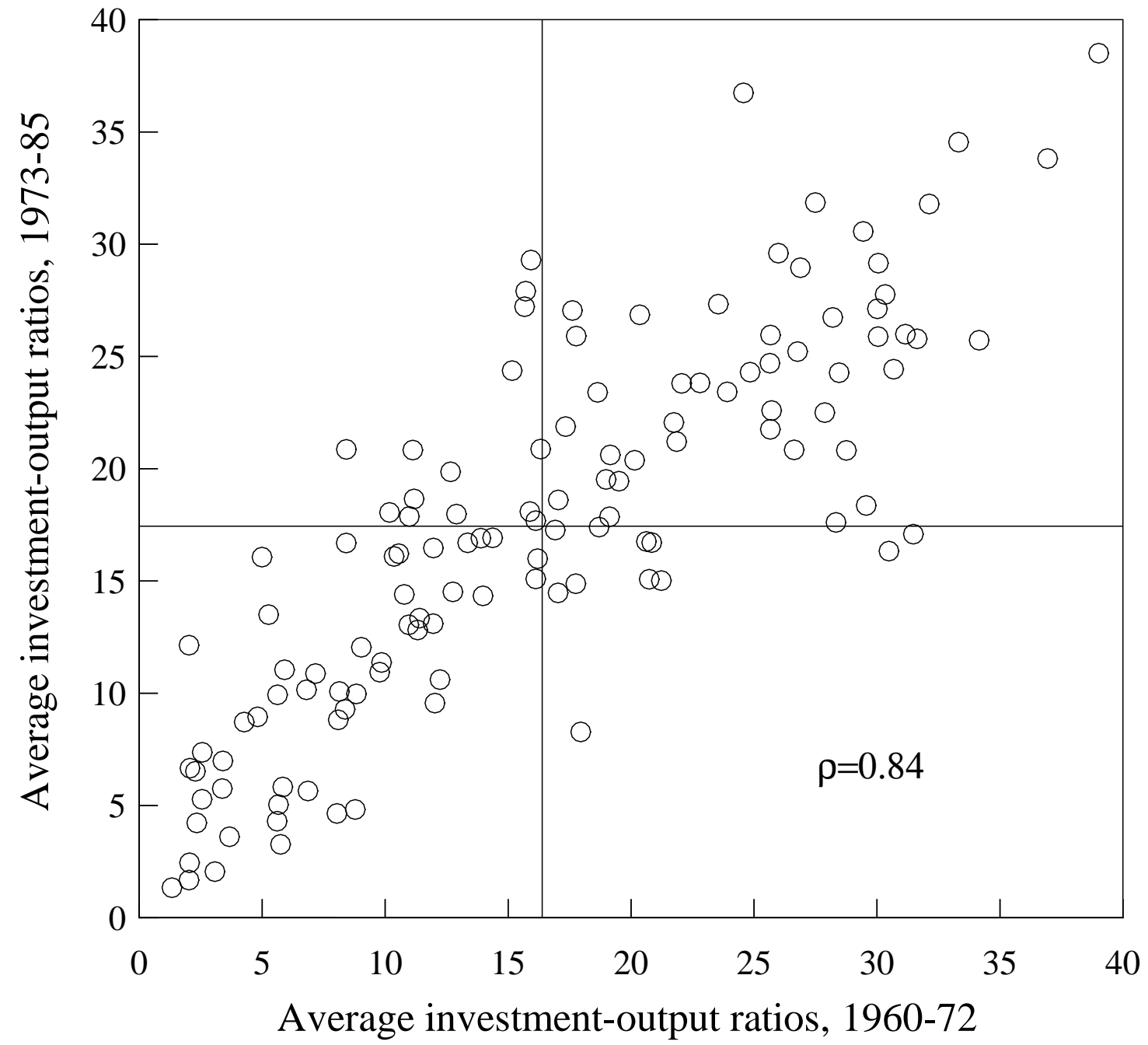

* The average investment-output ratio for $1960-72$ is 16.4 and the average investment-output ratio for 1973-85 is 17.4. 
Figure 5. The Cobb-Douglas Production Relation
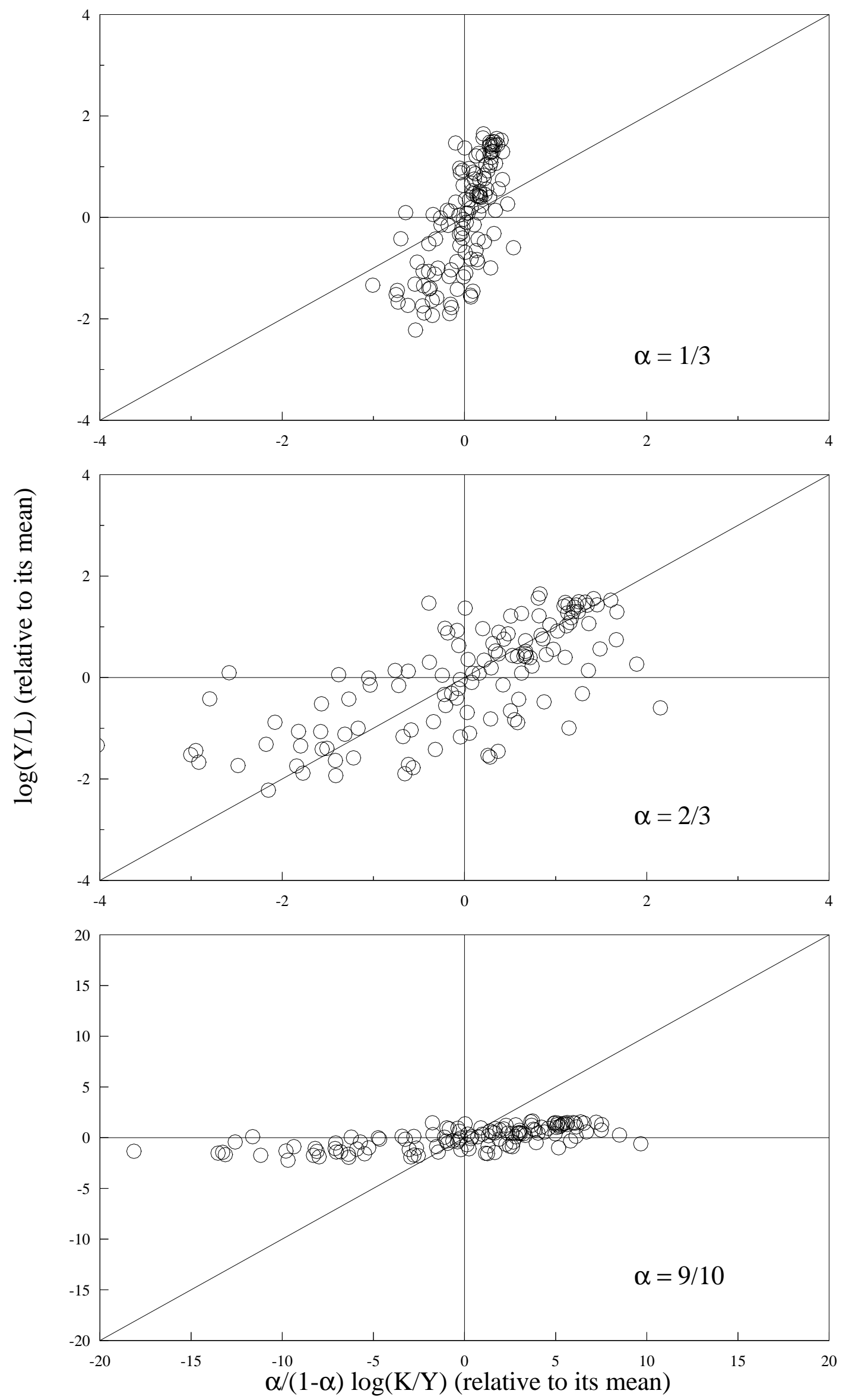
Figure 6. Persistence of Growth Rates in the Model

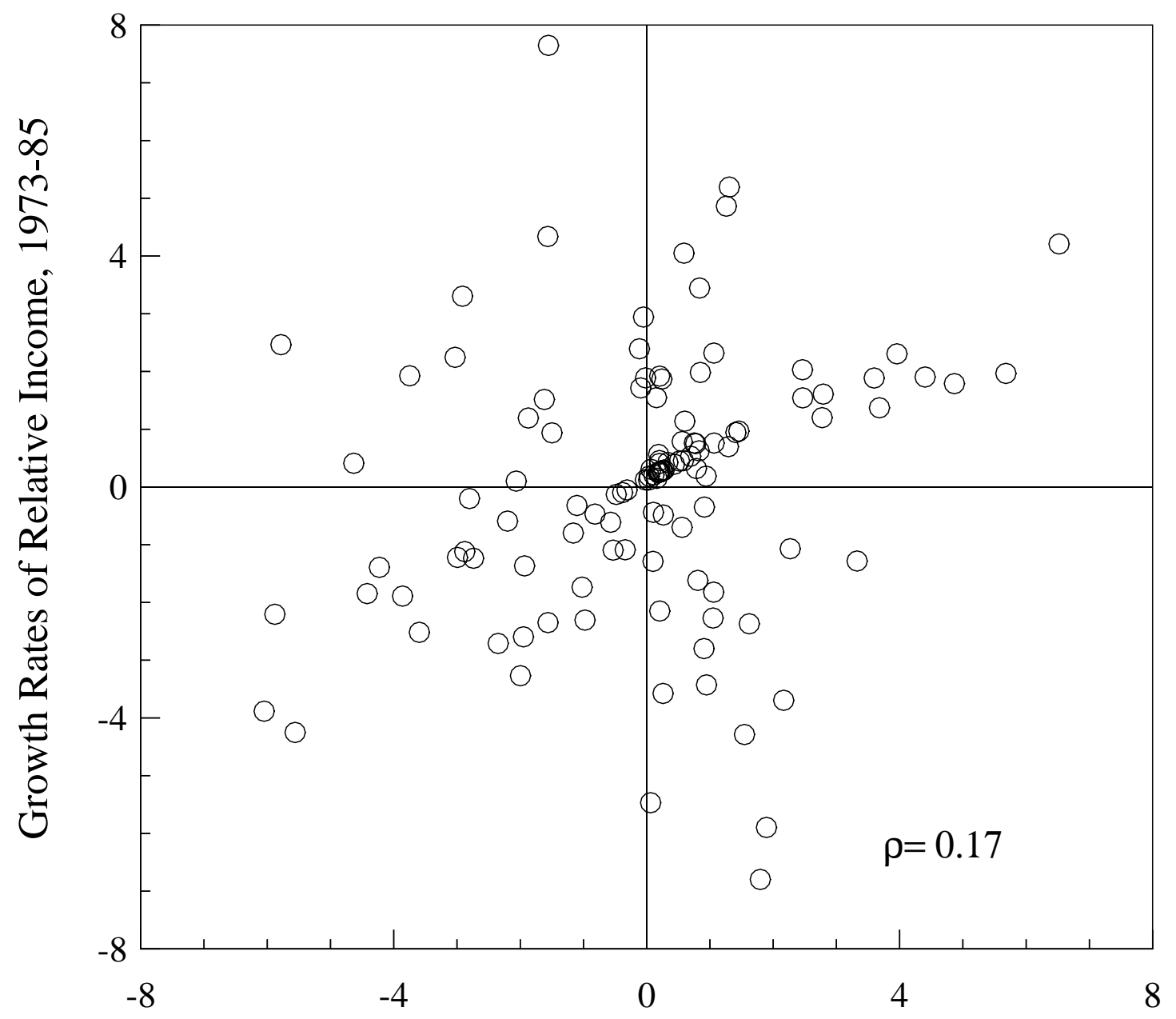

Growth Rates of Relative Income, 1961-72 
Figure 7. Persistence of Investment-Output Ratios in the Model*



*The average investment-output ratio for $1960-72$ is 13.7 and the average investment-output ratio for 1973-85 is 13.2. 
Table 1

Mobility Matrix for Relative Incomes ${ }^{\dagger}$

\begin{tabular}{|c|c|c|c|c|c|c|c|}
\hline $\begin{array}{l}\% \text { Obs. in } \\
1960\end{array}$ & 60 & $1 / 8-1 / 4$ & $1 / 4-1 / 2$ & $1 / 2-1$ & $1-2$ & $2-4$ & $4-8$ \\
\hline 8.8 & $1 / 8-1 / 4$ & .82 & .09 & .09 & & & \\
\hline 15.2 & $1 / 4-1 / 2$ & .37 & .47 & .11 & .05 & & \\
\hline 25.6 & $1 / 2-1$ & .09 & .22 & .41 & .28 & & \\
\hline 24.8 & $1-2$ & & & .13 & .55 & .32 & \\
\hline 17.6 & $2-4$ & & & & .14 & .59 & .27 \\
\hline 8.0 & $4-8$ & & & & & .20 & .80 \\
\hline \multicolumn{2}{|c|}{ \% Obs. in 1985} & 15.2 & 13.6 & 16.0 & 24.0 & 20.0 & 11.2 \\
\hline
\end{tabular}

The entries in the matrix are the fractions of countries which were in the specified bin in 1960 and ended up in the specified bin in 1985 . 
Table 2

A. Statistics for the Miracles (1960-85)

\begin{tabular}{lccc}
\hline & $\begin{array}{c}\text { Average Growth } \\
\text { of Relative Income }\end{array}$ & $\begin{array}{c}\text { Average } \\
\text { I/Y }\end{array}$ & $\begin{array}{c}\text { Relative Income } \\
\text { in } 1960\end{array}$ \\
\hline Botswana & 4.8 & 19.8 & 0.33 \\
Romania & 4.6 & 29.7 & 0.20 \\
Hong Kong & 3.3 & 20.3 & 1.11 \\
Korean Republic & 3.2 & 21.4 & 0.72 \\
Japan & 3.2 & 33.9 & 1.33 \\
Taiwan & 3.2 & 21.8 & 0.90 \\
Singapore & 3.0 & 30.7 & 1.34 \\
Lesotho & 2.9 & 9.4 & 0.15 \\
Jordan & 2.8 & 14.1 & 1.20 \\
Malta & 2.5 & 23.7 & 1.26 \\
Miracle Average & 3.3 & 21.2 & 0.68 \\
World Average & 0 & 14.1 & 1.00 \\
\hline
\end{tabular}

B. Statistics for the Disasters (1960-85)

\begin{tabular}{lccc}
\hline & $\begin{array}{c}\text { Average Growth } \\
\text { of Relative Income }\end{array}$ & $\begin{array}{c}\text { Average } \\
\text { I/Y }\end{array}$ & $\begin{array}{c}\text { Relative Income } \\
\text { in } 1960\end{array}$ \\
\hline Chad & -4.2 & 2.1 & 0.51 \\
Guyana & -3.9 & 24.8 & 1.50 \\
Madagascar & -3.4 & 1.3 & 0.62 \\
Mozambique & -3.3 & 1.9 & 0.51 \\
Somalia & -2.9 & 8.5 & 0.51 \\
Venezuela & -2.6 & 18.6 & 5.46 \\
Angola & -2.6 & 3.6 & 0.52 \\
Zambia & -2.6 & 24.3 & 0.71 \\
Burundi & -2.5 & 4.4 & 0.28 \\
Uganda & -2.1 & 2.6 & 0.32 \\
Disaster Average & -3.0 & 5.4 & 0.68 \\
World Average & 0 & 14.1 & 1.00 \\
\hline
\end{tabular}


Table 3

Average Investment-Output Ratios in Each Cell ${ }^{\dagger}$

\begin{tabular}{|c|c|c|c|c|c|c|c|}
\hline $\begin{array}{l}\% \text { Obs. } \\
\text { in } 1960\end{array}$ & $60 \quad 85$ & $1 / 8-1 / 4$ & $1 / 4-1 / 2$ & $1 / 2-1$ & $1-2$ & $2-4$ & $4-8$ \\
\hline 8.8 & $1 / 8-1 / 4$ & 9.4 & 9.4 & 29.7 & & & \\
\hline 15.2 & $1 / 4-1 / 2$ & 4.8 & 11.2 & 10.7 & 19.8 & & \\
\hline 25.6 & $1 / 2-1$ & 3.3 & 6.3 & 12.2 & 17.1 & & \\
\hline 24.8 & $1-2$ & & & 15.5 & 17.9 & 24.1 & \\
\hline 17.6 & $2-4$ & & & & 16.6 & 21.7 & 22.3 \\
\hline 8.0 & $4-8$ & & & & & 15.3 & 25.6 \\
\hline \multicolumn{2}{|c|}{ \% Obs. in 1985} & 15.2 & 13.6 & 16.0 & 24.0 & 20.0 & 11.2 \\
\hline
\end{tabular}

${ }^{\dagger}$ The entires in the matrix are the average investment-output ratios for countries which were in the specified bin in 1960 and ended up in the specified bin in 1985 . 
Table 4

\section{Parameters}

Stochastic Process for Distortions ${ }^{\dagger}$

Autoregressive Parameters

$$
\begin{array}{rrr}
\rho_{\mathrm{p}}=0.993, & \mu_{\mathrm{p}}=1.976, & \sigma_{\mathrm{p}}=0.074 \\
(0.002) & (0.324) & (0.002) \\
\rho_{\mathrm{T}}=0.865, & \mu_{\mathrm{T}}=2.459, & \sigma_{\mathrm{T}}=0.789 \\
(0.018) & (0.219) & (0.024)
\end{array}
$$

Switching Probability Parameters

$$
\begin{array}{rr}
\mathrm{a}_{\mathrm{p}}=0.244, & \mathrm{~b}_{\mathrm{p}}=-0.012 \\
(0.021) & (0.001) \\
\mathrm{a}_{\mathrm{T}}=0.350, & \mathrm{~b}_{\mathrm{T}}=-0.016 \\
(0.031) & (0.003)
\end{array}
$$

\section{Preferences}

$$
\begin{aligned}
& \beta=0.94 \\
& \sigma=1.5
\end{aligned}
$$

Technology

$$
\begin{aligned}
& \alpha_{\mathrm{k}}=\alpha_{\mathrm{h}}=1 / 3 \\
& \delta_{\mathrm{k}}=\delta_{\mathrm{h}}=0.06 \\
& \mathrm{~g}=0.023 \\
& \mathrm{n}=0.019
\end{aligned}
$$

${ }^{\dagger}$ Numbers in parentheses are standard errors. 
Table 5

Model's Mobility Matrix for Relative Incomes ${ }^{\dagger}$

\begin{tabular}{|c|c|c|c|c|c|c|c|}
\hline $\begin{array}{c}\% \text { Obs. in } \\
1960\end{array}$ & 60 & $1 / 8-1 / 4$ & $1 / 4-1 / 2$ & $1 / 2-1$ & $1-2$ & $2-4$ & $4-8$ \\
\hline 8.8 & $1 / 8-1 / 4$ & $\begin{array}{c}.73 \\
(.09)\end{array}$ & $\begin{array}{c}.19 \\
(.10)\end{array}$ & $\begin{array}{c}.06 \\
(.07)\end{array}$ & $\begin{array}{c}.02 \\
(.03)\end{array}$ & & \\
\hline 15.2 & $1 / 4-1 / 2$ & $\begin{array}{c}.11 \\
(.09)\end{array}$ & $\begin{array}{c}.57 \\
(.12)\end{array}$ & $\begin{array}{c}.19 \\
(.08)\end{array}$ & $\begin{array}{c}.10 \\
(.06)\end{array}$ & $\begin{array}{c}.03 \\
(.04)\end{array}$ & \\
\hline 25.6 & $1 / 2-1$ & $\begin{array}{c}.00 \\
(.01)\end{array}$ & $\begin{array}{l}.13 \\
(.05)\end{array}$ & $\begin{array}{c}.61 \\
(.08)\end{array}$ & $\begin{array}{l}.21 \\
(.07)\end{array}$ & $\begin{array}{c}.04 \\
(.03)\end{array}$ & $\begin{array}{c}.00 \\
(.01)\end{array}$ \\
\hline 24.8 & $1-2$ & & $\begin{array}{l}.03 \\
(.02)\end{array}$ & $\begin{array}{l}.28 \\
(.07)\end{array}$ & $\begin{array}{l}.51 \\
(.08)\end{array}$ & $\begin{array}{l}.17 \\
(.05)\end{array}$ & $\begin{array}{c}.01 \\
(.02)\end{array}$ \\
\hline 17.6 & $2-4$ & & & $\begin{array}{l}.09 \\
(.05)\end{array}$ & $\begin{array}{c}.35 \\
(.09)\end{array}$ & $\begin{array}{l}.39 \\
(.08)\end{array}$ & $\begin{array}{l}.17 \\
(.05)\end{array}$ \\
\hline 8.0 & $4-8$ & & & & $\begin{array}{l}.05 \\
(.06)\end{array}$ & $\begin{array}{l}.21 \\
(.10)\end{array}$ & $\begin{array}{c}.74 \\
(.10)\end{array}$ \\
\hline \multicolumn{2}{|c|}{ \% Obs. in 1985} & $\begin{array}{c}8.2 \\
(1.8)\end{array}$ & $\begin{array}{l}14.5 \\
(2.3)\end{array}$ & $\begin{array}{l}27.6 \\
(3.3)\end{array}$ & $\begin{array}{l}26.2 \\
(3.4)\end{array}$ & $\begin{array}{l}14.2 \\
(2.3)\end{array}$ & $\begin{array}{c}8.3 \\
(1.3)\end{array}$ \\
\hline
\end{tabular}

The entries in the matrix are the fractions of countries which were in the specified bin in 1960 and ended up in the specified bin in 1985. Numbers in parentheses are standard deviations across 100 simulations. 
Table 6A

Model's Statistics for the Miracles

I. A Single Realization

\begin{tabular}{lccc}
\hline Miracle & $\begin{array}{c}\text { Average Growth of } \\
\text { Relative Income }\end{array}$ & $\begin{array}{c}\text { Average } \\
\text { I/Y }\end{array}$ & $\begin{array}{c}\text { Relative Income } \\
\text { in } 1960\end{array}$ \\
\hline 1 & 5.2 & 23.0 & 0.46 \\
2 & 5.0 & 15.2 & 0.21 \\
3 & 4.7 & 21.1 & 0.45 \\
4 & 4.1 & 49.0 & 1.30 \\
5 & 3.6 & 31.9 & 1.19 \\
6 & 3.3 & 10.0 & 0.22 \\
7 & 3.2 & 21.4 & 0.73 \\
8 & 2.9 & 15.5 & 0.55 \\
9 & 2.9 & 23.4 & 0.53 \\
10 & 2.6 & 18.5 & 0.57 \\
& & & \\
Miracle Average & 3.7 & 21.0 & 0.53 \\
\hline
\end{tabular}

II. Across Realizations ${ }^{\dagger}$

\begin{tabular}{lccc}
\hline & $\begin{array}{c}\text { Average Growth of } \\
\text { Relative Income }\end{array}$ & $\begin{array}{c}\text { Average } \\
\text { I/Y }\end{array}$ & $\begin{array}{c}\text { Relative Income } \\
\text { in } 1960\end{array}$ \\
\hline Mean of Miracle Average & 4.45 & 23.80 & 0.58 \\
& $(.50)$ & $(3.45)$ & $(.12)$ \\
Mean of World Average & 0 & 11.63 & 1.00 \\
& & $(.48)$ & \\
\hline
\end{tabular}

${ }^{\dagger}$ Numbers in parentheses are standard deviations across 100 simulations. 
Table 6B

Model's Statistics for Disasters

I. A Single Realization

\begin{tabular}{lccc}
\hline Disaster & $\begin{array}{c}\text { Average Growth of } \\
\text { Relative Income }\end{array}$ & $\begin{array}{c}\text { Average } \\
\text { I/Y }\end{array}$ & $\begin{array}{c}\text { Relative Income } \\
\text { in } 1960\end{array}$ \\
\hline 1 & -5.6 & 2.2 & 3.50 \\
2 & -4.6 & 4.8 & 3.04 \\
3 & -4.4 & 4.1 & 2.56 \\
4 & -4.3 & 3.4 & 1.43 \\
5 & -4.2 & 4.8 & 2.20 \\
6 & -3.7 & 4.8 & 1.51 \\
7 & -3.5 & 7.6 & 2.96 \\
8 & -2.9 & 4.5 & 0.87 \\
9 & -2.7 & 8.9 & 2.67 \\
10 & -2.7 & 7.8 & 1.63 \\
& & & \\
Disaster Average & -3.9 & 4.9 & 2.07 \\
\hline
\end{tabular}

II. Across Realizations ${ }^{\dagger}$

\begin{tabular}{lccc}
\hline Disaster & $\begin{array}{c}\text { Average Growth of } \\
\text { Relative Income }\end{array}$ & $\begin{array}{c}\text { Average } \\
\text { I/Y }\end{array}$ & $\begin{array}{c}\text { Relative Income } \\
\text { in } 1960\end{array}$ \\
\hline Mean of Disaster Average & -3.75 & 5.19 & 2.17 \\
& $(.27)$ & $(.75)$ & $(.30)$ \\
Mean of World Average & 0 & 11.63 & 1.00 \\
& & $(.48)$ & \\
\hline
\end{tabular}

${ }^{\dagger}$ Numbers in parentheses are standard deviations across 100 simulations. 
Table 7

Average Investment-Output Ratios in Model in Each Cell ${ }^{\dagger}$

\begin{tabular}{|c|c|c|c|c|c|c|c|}
\hline $\begin{array}{c}\% \text { Obs. in } \\
1960\end{array}$ & 60 & $1 / 8-1 / 4$ & $1 / 4-1 / 2$ & $1 / 2-1$ & $1-2$ & $2-4$ & $4-8$ \\
\hline 8.8 & $1 / 8-1 / 4$ & $\begin{array}{l}4.5 \\
(.1)\end{array}$ & $\begin{array}{c}6.8 \\
(1.1)\end{array}$ & $\begin{array}{l}13.2 \\
(2.5)\end{array}$ & $\begin{array}{l}24.4 \\
(6.0)\end{array}$ & & \\
\hline 15.2 & $1 / 4-1 / 2$ & $\begin{array}{l}4.3 \\
(.2)\end{array}$ & $\begin{array}{l}6.1 \\
(.4)\end{array}$ & $\begin{array}{l}11.6 \\
(1.5)\end{array}$ & $\begin{array}{l}21.0 \\
(3.5)\end{array}$ & $\begin{array}{l}37.0 \\
(6.0)\end{array}$ & \\
\hline 25.6 & $1 / 2-1$ & $\begin{array}{l}2.6 \\
(.4)\end{array}$ & $\begin{array}{l}5.5 \\
(.8)\end{array}$ & $\begin{array}{l}9.4 \\
(.5)\end{array}$ & $\begin{array}{l}17.0 \\
(2.2)\end{array}$ & $\begin{array}{c}32.2 \\
(7.0)\end{array}$ & $\begin{array}{c}57.0 \\
(10.7)\end{array}$ \\
\hline 24.8 & $1-2$ & & $\begin{array}{l}3.3 \\
(.9)\end{array}$ & $\begin{array}{l}7.0 \\
(.8)\end{array}$ & $\begin{array}{r}13.8 \\
(.9)\end{array}$ & $\begin{array}{l}26.3 \\
(2.6)\end{array}$ & $\begin{array}{c}48.8 \\
(9.1)\end{array}$ \\
\hline 17.6 & $2-4$ & & & $\begin{array}{c}4.2 \\
(1.4)\end{array}$ & $\begin{array}{c}9.6 \\
(1.5)\end{array}$ & $\begin{array}{c}20.3 \\
(1.9)\end{array}$ & $\begin{array}{c}41.0 \\
(6.6)\end{array}$ \\
\hline 8.0 & $4-8$ & & & & $\begin{array}{c}7.0 \\
(3.2)\end{array}$ & $\begin{array}{l}16.2 \\
(3.8)\end{array}$ & $\begin{array}{c}36.2 \\
(3.0)\end{array}$ \\
\hline \multicolumn{2}{|c|}{ \% Obs. in 1985} & $\begin{array}{c}8.2 \\
(1.8)\end{array}$ & $\begin{array}{l}14.5 \\
(2.3)\end{array}$ & $\begin{array}{l}27.6 \\
(3.3)\end{array}$ & $\begin{array}{c}26.2 \\
(3.4)\end{array}$ & $\begin{array}{l}14.2 \\
(2.3)\end{array}$ & $\begin{array}{c}8.3 \\
(1.3)\end{array}$ \\
\hline
\end{tabular}

${ }^{\dagger}$ The entries in the matrix are the average investment-output ratios for countries which were in the specified bin in 1960 and ended up in the specified bin in 1985. Numbers in parentheses are standard deviations across 100 simulations. 
Federal Reserve Bank of Minneapolis

Research Department Staff Report 204

Revised October 1997

\section{APPENDICES for \\ The Poverty of Nations: \\ A Quantitative Investigation \\ (Not Intended for Publication)}

V. V. Chari*

University of Minnesota and

Federal Reserve Bank of Minneapolis

Patrick J. Kehoe*

University of Pennsylvania and

Federal Reserve Bank of Minneapolis

Ellen R. McGrattan*

Federal Reserve Bank of Minneapolis

\footnotetext{
${ }^{*}$ The views expressed herein are those of the authors and not necessarily those of the Federal Reserve Bank of Minneapolis or the Federal Reserve System.
} 


\section{Appendix 1}

In this appendix we describe the log-likelihood function used in our estimation of the stochastic process for the distortions. We begin by describing our construction of the log-likelihood function for a given country. Since we assume that the distortions are independently drawn across countries the log-likelihood function that we use in our estimation is simply the sum of the log-likelihood functions for each country. Let $s=(R, \tau)$ denote the state of the system. Since there are two regimes $R=1,2$ and $\tau$ goes from 1 to 20 , there are 40 states. Let $P$ denote the transition matrix for $s_{t}$, with typical element $p_{i j}=\operatorname{Prob}\left\{s_{t+1}=j \mid s_{t}=i\right\}$. This transition matrix depends on the parameters of the switching probability functions. Let $z_{t}$ denote the prior probability distribution over the states at date $t$ with typical element $z_{j t}$. Let $x_{t}$ denote the posterior distribution at $t$, conditional on having observed the relative price at $t$, with typical element $x_{j t}$. Then we have

$$
z_{t+1}=P^{\prime} x_{t}
$$

Bayes' rule is used to calculate the posterior distribution from the prior distribution and the current observation so that we have

$$
x_{j t}=\operatorname{Prob}\left\{s_{t}=j \mid \theta_{t}, \Theta_{t-1} ; \gamma\right\}=\frac{z_{j t} \operatorname{Prob}\left\{\theta=\theta_{t} \mid s_{t}=j, \Theta_{t-1} ; \gamma\right\}}{\sum_{j} z_{j t} \operatorname{Prob}\left\{\theta=\theta_{t} \mid s_{t}=j, \Theta_{t-1} ; \gamma\right\}},
$$

where $\Theta_{t}=\left(\theta_{t}, \theta_{t-1}, \ldots, \theta_{1}\right)^{\prime}$ is a vector containing all observations of the relative price through

year $t$. The term $\operatorname{Prob}\left\{\theta=\theta_{t} \mid s_{t}=j, \Theta_{t-1} ; \gamma\right\}$ can be calculated using the assumption that the innovations are normally distributed.

The log-likelihood function for each country is given by

$$
\mathcal{L}(\gamma)=\sum_{t=1}^{T} \log f\left(\theta_{t} \mid \Theta_{t-1} ; \gamma\right)
$$

where $f$ is the conditional density and $T$ is the number of years. We can write the conditional density function as

$$
f\left(\theta_{t} \mid \Theta_{t-1} ; \gamma\right)=\sum_{j} z_{j t} \operatorname{Prob}\left\{\theta=\theta_{t} \mid s_{t}=j, \Theta_{t-1} ; \gamma\right\}
$$

The initial prior $z_{0}$ is chosen to be identical to the stationary distribution associated with $P$. 


\section{Appendix 2}

In this appendix we describe how we construct the labor share of income associated with the production of consumption and investment goods. We use the 1987 benchmark input-output accounts for the U.S. economy (Survey of Current Business 1994). We begin by describing the conceptual framework underlying our calculations. Suppose that there are $N$ industries, each producing a unique commodity. Let $A$ denote the unit-input requirements matrix, where $a_{i j}$ gives the dollar value of commodity $i$ used by industry $j$ as an intermediate input to produce 1 dollar of total output by industry $j$. That is, total output by industry is given by

$$
Y=A Y+D
$$

where $Y_{i}, i=1, \ldots, N$ gives total output of commodity $i$ in the economy $D_{i}, i=1, \ldots, N$, gives the dollar value of commodity $i$ used for final demand and the $i^{\text {th }}$ element of the vector $A Y$ gives the dollar value of commodity $i$ used as an intermediate input. Suppose that final demand $D$ can be allocated between two sectors, a consumption goods sector $C$ and an investment goods sector $I$ so that

$$
D=C+I
$$

Then we can define the total output vector associated with producing consumption goods by

$$
Y_{C}=A Y_{C}+C
$$

and the output vector associated with producing investment goods by

$$
Y_{I}=A Y_{I}+I .
$$

These yield

$$
Y_{C}=(I-A)^{-1} C
$$

and

$$
Y_{I}=(I-A)^{-1} I .
$$


Let $L S_{i}$ denote payments to labor in industry $i$ divided by total output of industry $i$ and let $R K_{i}$ denote payments to capital in industry $i$ divided by total output of industry $i$. Then we can define the labor share associated with producing consumption goods by

$$
L S C=\frac{Y_{C}^{\prime} L S}{Y_{C}^{\prime}(L S+R K)}
$$

and the labor share associated with producing investment goods by

$$
L S I=\frac{Y_{I}^{\prime} L S}{Y_{I}^{\prime}(L S+R K)}
$$

In practice, three complications arise. First, industries sometimes produce more than one commodity. Second, there are sectors of final demand other than consumption and investment. Third, indirect business taxes are a component of value-added and must be allocated between labor and capital. We modify the procedure above to deal with these complications as follows. We use three tables from the input-output accounts: the make table, the use table, and the input components table. The make table can be used to construct a matrix $M=\left(m_{i j}\right)$, where $m_{i j}$ gives the dollar amount of commodity $j$ produced by industry $i$ divided by total output of industry $i$. The use table can be used to construct two matrices $A$ and $D$. The element $a_{i j}$ of matrix $A$ gives the dollar amount of commodity $i$ used by industry $j$ divided by total output of industry $i$. The element $d_{i j}$ gives the dollar amount of commodity $i$ used by the final demand sectors of the economy. These final demand sectors are personal consumption expenditures $(P C)$, private fixed investment $(P I)$, change in business inventories $(P I N)$, net exports $(N X)$, and government purchases $(G)$. The input components table, denoted $S$, gives value-added by each industry and the breakdown of value-added into compensation of employees $(L C)$, indirect business taxes $(T)$, and other value-added $(O V)$.

We allocate sectors of final demand other than consumption and investment as pro-rata shares to consumption and investment. Specifically, consumption of commodity $i, C_{i}$ is given by

$$
C_{i}=P C_{i}\left[\frac{G D P_{i}}{P C_{i}+P I_{i}+P I N_{i}}\right]
$$


and investment in commodity $i, I_{i}$ is given by

$$
I_{i}=P I_{i}\left[\frac{G D P_{i}}{P C_{i}+P I_{i}+P I N_{i}}\right]
$$

where $G D P_{i}=P C_{i}+P I_{i}+P I N_{i}+N X_{i}+G_{i}$. Given this allocation of final demand to investment and consumption goods sectors, the analogue of (1) is

$$
Y_{C}=(M-A)^{-1} C
$$

and the analogue of $(2)$ is

$$
Y_{I}=(M-A)^{-1} I
$$

We allocate indirect business taxes proportionately to labor and to capital. Labor and capital shares as fractions of total industry output for each industry are thus given by

$$
L S_{i}=\frac{L C_{i}}{Y_{i}} \frac{\left[L C_{i}+O V_{i}+T_{i}\right]}{\left[L C_{i}+O V_{i}\right]}
$$

and

$$
R K_{i}=\frac{O V_{i}}{Y_{i}} \frac{\left[L C_{i}+O V_{i}+T_{i}\right]}{\left[L C_{i}+O V_{i}\right]}
$$

We can now use (3) and (4) to calculate labor share and capital share associated with producing consumption and investment goods. 


\section{Data Appendix}

All of our data are from the Penn World Table (PWT), Mark 5.6. Our measure of output per worker in the PWT is denoted by RGDPW. Where necessary, we construct our measure of GDP by multiplying the PWT's real GDP per capita in constant dollars (RGDPCH) by population (POP). We obtain investment data by multiplying the PWT's measure of investment share of GDP (I) by our constructed measure of GDP.

Table A1 of this appendix is a list of the countries in our sample, together with relative incomes in 1960 and 1985, growth rates of relative income from 1960 to 1985, average investmentoutput ratios, and the capital-output ratio in 1985, which is calculated according to the method described in the text. Table A2 lists each country by its location in the mobility matrix. The entries in parentheses below the country name give relative starting incomes (in 1960) and ending incomes (in 1985). 
Table A1

\begin{tabular}{|c|c|c|c|c|c|}
\hline & \multicolumn{2}{|c|}{ Relative Income } & \multirow[b]{2}{*}{$\begin{array}{l}\text { Growth Rate of } \\
\text { Relative Income }\end{array}$} & \multirow[b]{2}{*}{$\mathrm{I} / \mathrm{Y}$} & \multirow[b]{2}{*}{$\mathrm{K} / \mathrm{Y}$} \\
\hline & 1960 & 1985 & & & \\
\hline \multicolumn{6}{|l|}{$\overline{\text { Africa }}$} \\
\hline Algeria & 1.74 & 2.07 & 0.69 & 21.81 & 2.22 \\
\hline Angola & 0.52 & 0.27 & -2.59 & 3.64 & 0.53 \\
\hline Benin & 0.53 & 0.37 & -1.42 & 6.49 & 0.89 \\
\hline Botswana & 0.33 & 1.05 & 4.76 & 19.77 & 1.41 \\
\hline Burkina Faso & 0.21 & 0.14 & -1.42 & 6.88 & 0.78 \\
\hline Burundi & 0.28 & 0.15 & -2.47 & 4.40 & 0.65 \\
\hline Cameroon & 0.36 & 0.60 & 2.04 & 7.78 & 0.72 \\
\hline Cape Verde Is. & 0.37 & 0.44 & 0.66 & 23.60 & 2.09 \\
\hline Central Afr. R. & 0.31 & 0.19 & -1.86 & 6.80 & 0.78 \\
\hline Chad & 0.51 & 0.18 & -4.19 & 2.25 & 0.46 \\
\hline Comoros & 0.29 & 0.22 & -1.17 & 14.22 & 1.81 \\
\hline Congo & 0.67 & 1.06 & 1.87 & 11.42 & 0.80 \\
\hline Egypt & 0.75 & 1.10 & 1.56 & 4.57 & 0.44 \\
\hline Ethiopia & 0.14 & 0.11 & -1.11 & 4.95 & 0.54 \\
\hline Gabon & 0.94 & 1.49 & 1.84 & 22.61 & 2.76 \\
\hline Gambia & 0.30 & 0.25 & -0.83 & 4.36 & 0.75 \\
\hline Ghana & 0.55 & 0.34 & -1.82 & 6.34 & 0.72 \\
\hline Guinea & 0.25 & 0.24 & -0.07 & 6.25 & 0.73 \\
\hline Guinea-Biss & 0.25 & 0.21 & -0.68 & 17.91 & 1.83 \\
\hline Ivory Coast & 0.54 & 0.58 & 0.25 & 12.07 & 1.43 \\
\hline Kenya & 0.39 & 0.31 & -0.89 & 16.32 & 1.55 \\
\hline Lesotho & 0.15 & 0.31 & 2.87 & 9.38 & 1.13 \\
\hline Liberia & 0.46 & 0.36 & -0.98 & 13.12 & 1.18 \\
\hline Madagascar & 0.62 & 0.26 & -3.40 & 1.33 & 0.21 \\
\hline Malawi & 0.20 & 0.18 & -0.50 & 10.54 & 1.17 \\
\hline Mali & 0.40 & 0.26 & -1.74 & 5.83 & 0.65 \\
\hline Mauritania & 0.57 & 0.41 & -1.28 & 15.03 & 2.12 \\
\hline Mauritius & 1.59 & 1.15 & -1.30 & 10.36 & 1.08 \\
\hline Morocco & 0.76 & 0.99 & 1.08 & 9.02 & 0.94 \\
\hline Mozambique & 0.51 & 0.22 & -3.33 & 1.85 & 0.35 \\
\hline Namibia & 1.31 & 1.30 & -0.02 & 27.92 & 4.08 \\
\hline Niger & 0.24 & 0.17 & -1.41 & 9.11 & 1.20 \\
\hline Nigeria & 0.35 & 0.44 & 0.91 & 13.38 & 1.83 \\
\hline Reunion & 0.98 & 1.21 & 0.85 & 23.96 & 1.84 \\
\hline Rwanda & 0.26 & 0.24 & -0.31 & 3.28 & 0.36 \\
\hline Senegal & 0.58 & 0.41 & -1.33 & 5.35 & 0.56 \\
\hline Seychelles & 0.67 & 1.09 & 1.93 & 15.98 & 1.66 \\
\hline Somalia & 0.51 & 0.24 & -2.91 & 8.48 & 1.35 \\
\hline
\end{tabular}


Table A1, continued

\begin{tabular}{|c|c|c|c|c|c|}
\hline & \multicolumn{2}{|c|}{ Relative Income } & \multirow[b]{2}{*}{$\begin{array}{l}\text { Growth Rate of } \\
\text { Relative Income }\end{array}$} & \multirow[b]{2}{*}{$\mathrm{I} / \mathrm{Y}$} & \multirow[b]{2}{*}{$\mathrm{K} / \mathrm{Y}$} \\
\hline & 1960 & 1985 & & & \\
\hline South Africa & 1.68 & 1.53 & -0.39 & 19.25 & 2.20 \\
\hline Swaziland & 0.67 & 0.80 & 0.76 & 12.37 & 1.54 \\
\hline Tanzania & 0.15 & 0.15 & -0.12 & 10.61 & 1.14 \\
\hline Togo & 0.21 & 0.23 & 0.40 & 16.26 & 1.91 \\
\hline Tunisia & 1.05 & 1.35 & 1.02 & 15.61 & 1.31 \\
\hline Uganda & 0.32 & 0.19 & -2.12 & 2.57 & 0.37 \\
\hline Zaire & 0.27 & 0.17 & -1.77 & 3.92 & 0.63 \\
\hline Zambia & 0.71 & 0.37 & -2.58 & 24.28 & 2.82 \\
\hline Zimbabwe & 0.60 & 0.50 & -0.70 & 18.12 & 1.61 \\
\hline \multicolumn{6}{|c|}{ North and Central America } \\
\hline Barbados & 1.80 & 1.88 & 0.19 & 12.53 & 1.54 \\
\hline Canada & 5.20 & 4.80 & -0.33 & 23.31 & 2.38 \\
\hline Costa Rica & 1.82 & 1.41 & -1.03 & 15.65 & 1.77 \\
\hline Dominican Republic & 1.10 & 1.09 & -0.04 & 14.43 & 1.72 \\
\hline El Salvador & 1.17 & 0.85 & -1.24 & 8.45 & 1.11 \\
\hline Guatemala & 1.41 & 1.13 & -0.88 & 9.40 & 1.17 \\
\hline Haiti & 0.45 & 0.33 & -1.24 & 4.97 & 0.82 \\
\hline Honduras & 0.87 & 0.72 & -0.79 & 14.16 & 1.42 \\
\hline Jamaica & 1.16 & 0.73 & -1.84 & 22.97 & 3.03 \\
\hline Mexico & 2.54 & 2.62 & 0.13 & 16.99 & 1.75 \\
\hline Nicaragua & 1.37 & 0.91 & -1.62 & 12.00 & 1.65 \\
\hline Panama & 1.27 & 1.55 & 0.80 & 21.90 & 2.06 \\
\hline Puerto Rico & 3.04 & 3.36 & 0.40 & 23.41 & 2.04 \\
\hline Trinidad \& Tobago & 4.51 & 3.93 & -0.55 & 12.59 & 1.59 \\
\hline United States & 6.52 & 5.20 & -0.90 & 21.53 & 2.40 \\
\hline \multicolumn{6}{|l|}{ South America } \\
\hline Argentina & 3.03 & 2.30 & -1.09 & 17.09 & 2.42 \\
\hline Bolivia & 0.89 & 0.87 & -0.10 & 18.77 & 1.96 \\
\hline Brazil & 1.48 & 1.69 & 0.53 & 19.88 & 1.88 \\
\hline Chile & 2.34 & 1.50 & -1.75 & 18.69 & 2.23 \\
\hline Colombia & 1.46 & 1.43 & -0.10 & 16.10 & 1.62 \\
\hline Ecuador & 1.19 & 1.48 & 0.88 & 22.93 & 2.27 \\
\hline Guyana & 1.50 & 0.55 & -3.93 & 24.78 & 4.65 \\
\hline Paraguay & 0.95 & 0.96 & 0.03 & 12.55 & 1.55 \\
\hline Peru & 1.68 & 1.25 & -1.18 & 17.82 & 2.30 \\
\hline Suriname & 1.90 & 1.68 & -0.50 & 19.48 & 2.22 \\
\hline Uruguay & 2.61 & 1.57 & -2.01 & 13.23 & 2.49 \\
\hline Venezuela & 5.46 & 2.83 & -2.60 & 18.60 & 2.53 \\
\hline \multicolumn{6}{|l|}{ Asia } \\
\hline Bangladesh & 0.74 & 0.66 & -0.47 & 4.51 & 0.39 \\
\hline China & 0.29 & 0.33 & 0.60 & 19.61 & 1.63 \\
\hline Hong Kong & 1.11 & 2.53 & 3.34 & 20.26 & 1.52 \\
\hline
\end{tabular}


Table A1, continued

\begin{tabular}{|c|c|c|c|c|c|}
\hline & \multicolumn{2}{|c|}{ Relative Income } & \multirow{2}{*}{$\begin{array}{l}\text { Growth Rate of } \\
\text { Relative Income }\end{array}$} & \multirow[b]{2}{*}{$\mathrm{I} / \mathrm{Y}$} & \multirow[b]{2}{*}{$\mathrm{K} / \mathrm{Y}$} \\
\hline & 1960 & 1985 & & & \\
\hline India & 0.47 & 0.42 & -0.46 & 13.63 & 1.34 \\
\hline Indonesia & 0.44 & 0.67 & 1.70 & 14.64 & 1.52 \\
\hline Iran & 2.68 & 2.13 & -0.90 & 14.92 & 1.97 \\
\hline Iraq & 3.43 & 2.44 & -1.35 & 10.53 & 1.92 \\
\hline Israel & 2.59 & 3.38 & 1.08 & 27.55 & 2.39 \\
\hline Japan & 1.33 & 2.90 & 3.15 & 33.93 & 3.14 \\
\hline Jordan & 1.20 & 2.41 & 2.83 & 14.12 & 1.45 \\
\hline Korea Republic & 0.72 & 1.60 & 3.22 & 21.44 & 1.91 \\
\hline Malaysia & 1.10 & 1.61 & 1.55 & 22.33 & 2.21 \\
\hline Myanmar & 0.18 & 0.21 & 0.44 & 8.83 & 0.86 \\
\hline Nepal & 0.34 & 0.35 & 0.04 & 5.19 & 0.64 \\
\hline Pakistan & 0.54 & 0.65 & 0.76 & 10.79 & 0.84 \\
\hline Philippines & 0.79 & 0.65 & -0.79 & 15.44 & 2.14 \\
\hline Saudi Arabia & 3.68 & 4.34 & 0.66 & 7.08 & 1.31 \\
\hline Singapore & 1.34 & 2.77 & 2.95 & 30.65 & 2.78 \\
\hline Sri Lanka & 0.94 & 0.86 & -0.33 & 8.48 & 0.95 \\
\hline Syria & 1.52 & 2.64 & 2.24 & 15.40 & 1.43 \\
\hline Taiwan & 0.90 & 1.96 & 3.15 & 21.84 & 1.85 \\
\hline Thailand & 0.50 & 0.73 & 1.51 & 16.90 & 1.48 \\
\hline \multicolumn{6}{|l|}{ Europe } \\
\hline Austria & 2.86 & 3.67 & 1.00 & 25.81 & 2.96 \\
\hline Belgium & 3.82 & 4.21 & 0.39 & 24.15 & 2.80 \\
\hline Cyprus & 1.33 & 2.14 & 1.94 & 27.97 & 2.44 \\
\hline Czechoslovakia & 0.89 & 1.15 & 1.04 & 27.80 & 3.13 \\
\hline Denmark & 3.95 & 3.67 & -0.29 & 26.37 & 2.88 \\
\hline Finland & 3.09 & 3.65 & 0.67 & 35.38 & 3.66 \\
\hline France & 3.60 & 4.17 & 0.59 & 27.47 & 3.11 \\
\hline Germany-West & 3.72 & 4.20 & 0.49 & 28.57 & 3.29 \\
\hline Greece & 1.38 & 2.50 & 2.43 & 25.99 & 2.64 \\
\hline Iceland & 3.36 & 3.58 & 0.25 & 29.60 & 2.80 \\
\hline Ireland & 2.24 & 2.96 & 1.11 & 25.44 & 2.83 \\
\hline Italy & 2.95 & 4.19 & 1.40 & 28.71 & 2.93 \\
\hline Luxembourg & 5.01 & 4.74 & -0.22 & 29.94 & 3.22 \\
\hline Malta & 1.26 & 2.37 & 2.54 & 23.73 & 2.02 \\
\hline Netherlands & 4.57 & 4.40 & -0.15 & 25.19 & 2.76 \\
\hline Norway & 3.82 & 4.43 & 0.60 & 31.96 & 3.08 \\
\hline Portugal & 1.30 & 1.75 & 1.20 & 23.67 & 2.58 \\
\hline Romania & 0.20 & 0.62 & 4.56 & 29.67 & 2.46 \\
\hline Spain & 2.19 & 3.26 & 1.61 & 25.17 & 2.85 \\
\hline Sweden & 4.63 & 4.08 & -0.51 & 23.71 & 2.74 \\
\hline Switzerland & 5.38 & 4.60 & -0.63 & 28.57 & 3.54 \\
\hline Turkey & 0.85 & 1.09 & 0.99 & 21.02 & 2.17 \\
\hline
\end{tabular}


Table A1, continued

\begin{tabular}{lccccc}
\hline \hline & \multicolumn{2}{c}{ Relative Income } & & & \\
\cline { 2 - 3 } & 1960 & 1985 & $\begin{array}{c}\text { Growth Rate of } \\
\text { Relative Income }\end{array}$ & I/Y & K/Y \\
\hline United Kingdom & 3.94 & 3.54 & -0.43 & 18.05 & 2.17 \\
U.S.S.R. & 1.25 & 2.11 & 2.13 & 38.76 & 3.65 \\
Yugoslavia & 1.13 & 1.76 & 1.79 & 30.00 & 3.34 \\
Oceania & & & & & \\
Australia & 5.14 & 4.46 & -0.57 & 29.05 & 2.97 \\
Fiji & 2.03 & 1.51 & -1.17 & 18.49 & 2.12 \\
New Zealand & 5.68 & 4.01 & -1.39 & 24.57 & 2.90 \\
Papua N. Guinea & 0.61 & 0.52 & -0.61 & 15.75 & 2.04 \\
\hline \hline
\end{tabular}


Table A2

Countries in the Mobility Matrix

Relative Income 1985

\begin{tabular}{|c|c|c|c|c|}
\hline & $1 / 8-1 / 4$ & $1 / 4-1 / 2$ & $1 / 2-1$ & $1-2$ \\
\hline $1 / 8-1 / 4$ & $\begin{array}{l}\text { Burkina Faso } \\
(.21-.14) \\
\text { Ethiopia } \\
\quad(.14-.11) \\
\text { Guinea } \\
\quad(.25-.24) \\
\text { Guinea Biss } \\
(.25-.21) \\
\text { Malawi } \\
\quad(.20-.18) \\
\text { Niger } \\
(.24-.17) \\
\text { Tanzania } \\
(.15-.15) \\
\text { Togo } \\
(.21-.23) \\
\text { Myanmar } \\
(.18-.21)\end{array}$ & $\begin{array}{l}\text { Lesotho } \\
\qquad(.15-.31)\end{array}$ & $\begin{array}{l}\text { Romania } \\
\qquad(.20-.62)\end{array}$ & \\
\hline $1 / 4-1 / 2$ & $\begin{array}{l}\text { Burundi } \\
(.28-.15) \\
\text { Central Africa } \\
(.31-.19) \\
\text { Comoros } \\
(.29-.22) \\
\text { Gambia } \\
(.30-.25) \\
\text { Rwanda } \\
\quad(.26-.24) \\
\text { Uganda } \\
(.32-.19) \\
\text { Zaire } \\
(.27-.17)\end{array}$ & $\begin{array}{l}\text { Cape Verde Is } \\
\quad(.37-.44) \\
\text { Kenya } \\
\quad(.39-.31) \\
\text { Liberia } \\
\quad(.46-.36) \\
\text { Mali } \\
\quad(.40-.26) \\
\text { Nigeria } \\
\quad(.35-.44) \\
\text { Haiti } \\
\quad(.45-.33) \\
\text { China } \\
\quad(.29-.33) \\
\text { India } \\
\quad(.47-.42) \\
\text { Nepal } \\
\quad(.34-.35)\end{array}$ & $\begin{array}{c}\text { Cameroon } \\
\quad(.36-.60) \\
\text { Indonesia } \\
\quad(.44-.67)\end{array}$ & $\begin{array}{l}\text { Botswana } \\
\quad(.33-1.05)\end{array}$ \\
\hline
\end{tabular}


Table A2, continued

\begin{tabular}{|c|c|c|c|c|}
\hline & $1 / 8-1 / 4$ & $1 / 4-1 / 2$ & $1 / 2-1$ & $1-2$ \\
\hline $1 / 2-1$ & $\begin{array}{l}\text { Chad } \\
\quad(.51-.18) \\
\text { Mozambique } \\
\quad(.51-.22) \\
\text { Somalia } \\
\quad(.51-.24)\end{array}$ & $\begin{array}{l}\text { Angola } \\
\quad(.52-.27) \\
\text { Benin } \\
\quad(.53-.37) \\
\text { Ghana } \\
\quad(.55-.34) \\
\text { Madagascar } \\
\quad(.62-.26) \\
\text { Mauritania } \\
\quad(.57-.41) \\
\text { Senegal } \\
\quad(.58-.41) \\
\text { Zambia } \\
\quad(.71-.37)\end{array}$ & $\begin{array}{c}\text { Ivory Coast } \\
(.54-.58) \\
\text { Morocco } \\
(.76-.99) \\
\text { Swaziland } \\
(.67-.80) \\
\text { Zimbabwe } \\
(.60-.50) \\
\text { Honduras } \\
(.87-.72) \\
\text { Bolivia } \\
(.89-.87) \\
\text { Paraguay } \\
(.95-.96) \\
\text { Bangladesh } \\
(.74-.66) \\
\text { Pakistan } \\
(.54-.65) \\
\text { Philippines } \\
(.79-.65) \\
\text { Sri Lanka } \\
(.94-.86) \\
\text { Thailand } \\
(.50-.73) \\
\text { Papua N. Guinea } \\
(.61-.52)\end{array}$ & $\begin{array}{l}\text { Congo } \\
\quad(.67-1.06) \\
\text { Egypt } \\
(.75-1.10) \\
\text { Gabon } \\
\quad(.94-1.49) \\
\text { Reunion } \\
\quad(.98-1.21) \\
\text { Seychelles } \\
\quad(.67-1.09) \\
\text { Korea Republic } \\
(.72-1.60) \\
\text { Taiwan } \\
\quad(.90-1.96) \\
\text { Czechoslovakia } \\
\quad(.89-1.15) \\
\text { Turkey } \\
(.85-1.09)\end{array}$ \\
\hline
\end{tabular}




\begin{tabular}{|c|c|c|c|c|}
\hline & $1 / 2-1$ & $1-2$ & $2-4$ & $4-8$ \\
\hline $1-2$ & $\begin{array}{c}\text { El Salvador } \\
(1.17-.85) \\
\text { Jamaica } \\
(1.16-.73) \\
\text { Nicaragua } \\
(1.37-.91) \\
\text { Guyana } \\
(1.50-.55)\end{array}$ & $\begin{array}{l}\text { Mauritius } \\
(1.59-1.15) \\
\text { Namibia } \\
(1.31-1.30) \\
\text { South Africa } \\
(1.68-1.53) \\
\text { Tunisia } \\
(1.05-1.35) \\
\text { Barbados } \\
(1.80-1.88) \\
\text { Costa Rica } \\
(1.82-1.41) \\
\text { Dominican Rep. } \\
(1.10-1.09) \\
\text { Guatemala } \\
(1.41-1.13) \\
\text { Panama } \\
(1.27-1.55) \\
\text { Brazil } \\
(1.48-1.69) \\
\text { Colombia } \\
(1.46-1.43) \\
\text { Ecuador } \\
(1.19-1.48) \\
\text { Peru } \\
(1.68-1.25) \\
\text { Suriname } \\
(1.90-1.68) \\
\text { Malaysia } \\
(1.10-1.61) \\
\text { Portugal } \\
(1.30-1.75) \\
\text { Yugoslavia } \\
(1.13-1.76)\end{array}$ & $\begin{array}{l}\text { Algeria } \\
\quad(1.74-2.07) \\
\text { Hong Kong } \\
(1.11-2.53) \\
\text { Japan } \\
\quad(1.33-2.90) \\
\text { Jordan } \\
\quad(1.20-2.41) \\
\text { Singapore } \\
\quad(1.34-2.77) \\
\text { Syria } \\
\quad(1.52-2.64) \\
\text { Cyprus } \\
\quad(1.33-2.14) \\
\text { Greece } \\
(1.38-2.50) \\
\text { Malta } \\
(1.26-2.37) \\
\text { U.S.S.R. } \\
(1.25-2.11)\end{array}$ & \\
\hline
\end{tabular}


Table A2, continued

\begin{tabular}{|c|c|c|c|c|}
\hline & $1 / 2-1$ & $1-2$ & $2-4$ & $4-8$ \\
\hline $2-4$ & & $\begin{array}{l}\text { Chile } \\
\quad(2.34-1.50) \\
\text { Uruguay } \\
\quad(2.61-1.57) \\
\text { Fiji } \\
\quad(2.03-1.51)\end{array}$ & $\begin{array}{l}\text { Mexico } \\
(2.54-2.62) \\
\text { Puerto Rico } \\
(3.04-3.36) \\
\text { Argentina } \\
(3.03-2.30) \\
\text { Iran } \\
\quad(2.68-2.13) \\
\text { Iraq } \\
\quad(3.43-2.44) \\
\text { Israel } \\
\quad(2.59-3.38) \\
\text { Austria } \\
\quad(2.86-3.67) \\
\text { Denmark } \\
\quad(3.95-3.67) \\
\text { Finland } \\
\quad(3.09-3.65) \\
\text { Iceland } \\
\quad(3.36-3.58) \\
\text { Ireland } \\
\quad(2.24-2.96) \\
\text { Spain } \\
(2.19-3.26) \\
\text { United Kingdom } \\
(3.94-3.54)\end{array}$ & $\begin{array}{l}\text { Saudi Arabia } \\
(3.68-4.34) \\
\text { Belgium } \\
\quad(3.82-4.21) \\
\text { France } \\
\quad(3.60-4.17) \\
\text { Germany Wes } \\
\quad(3.72-4.20) \\
\text { Italy } \\
\quad(2.95-4.19) \\
\text { Norway } \\
\quad(3.82-4.43)\end{array}$ \\
\hline $4-8$ & & & $\begin{array}{l}\text { Trinidad \& Tobago } \\
\quad(4.51-3.93) \\
\text { Venezuela } \\
(5.46-2.83)\end{array}$ & $\begin{array}{l}\text { Canada } \\
(5.20-4.80) \\
\text { United States } \\
(6.52-5.20) \\
\text { Luxembourg } \\
\quad(5.01-4.74) \\
\text { Netherlands } \\
(4.57-4.40) \\
\text { Sweden } \\
(4.63-4.08) \\
\text { Switzerland } \\
(5.38-4.60) \\
\text { Australia } \\
(5.14-4.46) \\
\text { New Zealand } \\
(5.68-4.01)\end{array}$ \\
\hline
\end{tabular}

